OPEN ACCESS

Edited by: Peng Qu,

National Institutes of Health (NIH),

United States

Reviewed by:

Lucas Ferrari De Andrade, Icahn School of Medicine at Mount

Sinai, United States

Alex Michael Abel,

LEAH Labs, Inc., United States

*Correspondence:

Quan Liao

lqpumc@126.com

${ }^{+}$These authors have contributed equally to this work

Specialty section:

This article was submitted to

Cancer Immunity

and Immunotherapy,

a section of the journal

Frontiers in Immunology

Received: 05 May 2021

Accepted: 24 May 2021

Published: 08 June 2021

Citation:

Zhang Y, Liu Q, Yang S

and Liao Q (2021) CD58

Immunobiology at a Glance.

Front. Immunol. 12:705260.

doi: 10.3389/fimmu.2021.705260

\section{CD58 Immunobiology at a Glance}

\author{
Yalu Zhang ${ }^{\dagger}$, Qiaofei Liu ${ }^{\dagger}$, Sen Yang and Quan Liao* \\ Department of General Surgery, State Key Laboratory of Complex Severe and Rare Diseases, Peking Union Medical College \\ Hospital, Chinese Academy of Medical Science and Peking Union Medical College, Beijing, China
}

The glycoprotein CD58, also known as lymphocyte-function antigen 3 (LFA-3), is a costimulatory receptor distributed on a broad range of human tissue cells. Its natural ligand CD2 is primarily expressed on the surface of T/NK cells. The CD2-CD58 interaction is an important component of the immunological synapse (IS) that induces activation and proliferation of T/NK cells and triggers a series of intracellular signaling in T/NK cells and target cells, respectively, in addition to promoting cell adhesion and recognition. Furthermore, a soluble form of CD58 (sCD58) is also present in cellular supernatant in vitro and in local tissues in vivo. The sCD58 is involved in T/NK cell-mediated immune responses as an immunosuppressive factor by affecting CD2-CD58 interaction. Altered accumulation of SCD58 may lead to immunosuppression of T/NK cells in the tumor microenvironment, allowing sCD58 as a novel immunotherapeutic target. Recently, the crucial roles of costimulatory molecule CD58 in immunomodulation seem to be reattracting the interests of investigators. In particular, the CD2-CD58 interaction is involved in the regulation of antiviral responses, inflammatory responses in autoimmune diseases, immune rejection of transplantation, and immune evasion of tumor cells. In this review, we provide a comprehensive summary of CD58 immunobiology.

Keywords: CD58, lymphocyte functional antigen-3, LFA-3, CD2, T cell activation, immune evasion

\section{INTRODUCTION}

Intercellular adhesion is vital for a range of immunological responses, including the interaction between $\mathrm{T}$ lymphocytes and target cells. Conjugate formation of $\mathrm{T}$ cells with antigen-negative targets is nearly as efficient as with specific target cells without causing lysis of target cells. Therefore, on specific target cells, adhesion in an antigen-independent manner may occur simultaneously with or prior to antigen recognition (1).

The immune adhesion molecule CD58, also known as LFA-3, is a heavily glycosylated, distributed surface glycoprotein of $40-70 \mathrm{kDa}$ and extensively expressed on hematopoietic and nonhematopoietic cells $(2,3)$. CD58 on the cell surface participates in potentiating effector-target adhesion during antigenspecific recognition (4). Cell-cell adhesion is crucial for leucocyte-mediated chemotaxis, phagocytosis, cytotoxicity, and induction of lymphocyte differentiation and proliferation. In terms of the antigenpresenting process, the CD58 molecule offers an effective second signal for T cell activation, thereby optimizing and replenishing the proliferative response mediated through TCR/CD3 signaling (Figure 1A) $(5,6)$.

CD2, also known as T11, LFA-2, the erythrocyte (E) rosette receptor, is the natural ligand of CD58. It is a surface glycoprotein restricted to T lymphocytes, NK cells, thymocytes, and a subset of bone marrow cells $(7,8)$. Both CD2 and CD58 are members of the immunoglobulin supergene family and their amino 


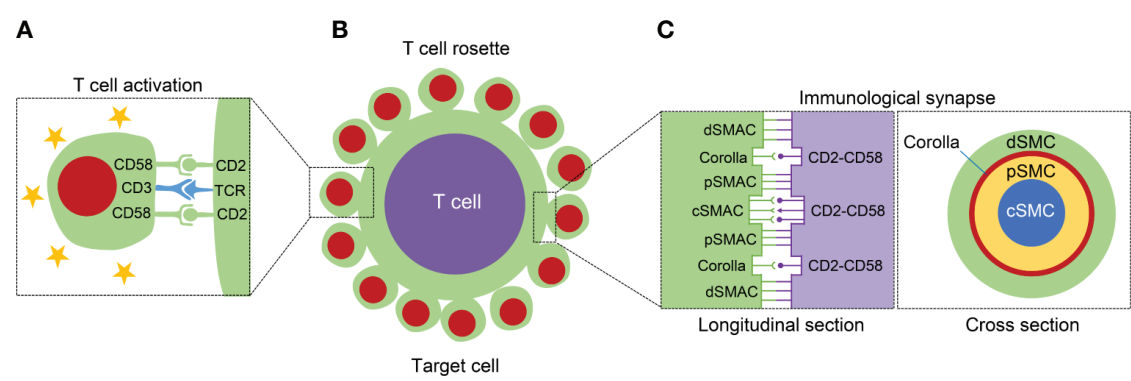

FIGURE 1 | The structure diagram with regard to T cell activation, T cell rosette, and immunological synapse (IS). (A) The left panel displays that the CD2-CD58 interaction facilitates the $T$ cell activation through offering the necessary second signal and assisting TCR-mediated stimulation. (B) The middle panel exhibits the formation of $\mathrm{T}$ cell rosette mainly mediated by the binding of CD2 with CD58. (C) The IS can be classified into different supramolecular activation complexes (SMAC), central, peripheral, and distal SMAC (c, p and dSMAC, respectively). In addition to the cSMAC, the CD2-CD58 interactions exist between pSMAC and dSMAC, and form a ring-like structure, called "corolla". The right panel shows the longitudinal and cross section of IS.

acid sequences on the extracellular domain are significantly similar (9). The amino-terminal domain of CD2 is responsible for target cell adhesion and binds to CD58 on target cells or antigenpresenting cells (APC) with high affinity (10-12). As an important adhesion pathway between $\mathrm{T}$ cells and target cells, CD2-CD58 interaction is not only a crucial costimulatory signal for optimal $\mathrm{T}$ cell activation in response to antigens, but also induction of a series of essential signal transduction events to participate in the modulation of $\mathrm{T}$ cell responses $(13,14)$. For example, incubation of $\mathrm{B}$ lymphoblastoid cell with immobilized anti-CD58 mAbs causes broad tyrosine phosphorylation and increases TNF- $\alpha$ production (15). Accumulating evidence has demonstrated that the CD2-CD58 interaction plays a critical role in lymphocyte activation, recirculation, and effector function, e.g., cytolytic activity on neoplastic cells $(16,17)$.

Herein, we have collated almost all of the published literature from discovery to the present and elaborately summarized the CD58 immunobiology in a systematic and comprehensive manner, including CD58 isoforms, sCD58, IS formation, CD58 polymorphisms, CD2-CD58 interaction, their structures of interface, and related functions; simultaneously dissected the important effects of CD58 for T/NK cell-mediated immune response in tumor-related and immune-related diseases.

\section{TWO ISOFORMS OF CD58}

There are two isoforms of CD58 derived from divergent mRNA splicing: a type-I transmembrane and a glycosylphosphatidylinositol (GPI)-anchored form (Figure 2A) (18). The former has an extracellular domain with six N-linked glycosylation sites sequentially linked to a hydrophobic transmembrane region and a 12-amino acid cytoplasmic segment; The latter is anchored to the outer side of the cell membrane by a GPI tail without transmembrane region and cytoplasmic domain $(18,19)$. They are located in different membrane compartments. The GPI-anchored isoform resides in lipid raft, whereas the transmembrane isoform localizes in a non-raft microdomain (20). Despite the transmembrane CD58 outside lipid rafts, it can trigger signaling independently of the GPI-anchored isoform, such as induction of tyrosine phosphorylation of PLC $\gamma$, SYK and BLNK, and activation of AKT and ERK $(20,21)$. Cell adhesion is dependent on the density of CD58. At lower densities, GPI-linked isoform is crucial for enhancing adhesion, instead of the transmembrane isoform (22). Accordingly, unlike the well-accepted concept that the GPI-anchor is indispensable for signaling, the GPI-anchored CD58 is more effective in enhancing adhesion, whereas the transmembrane form is more critical for signal transduction. This kind of structural distribution is of great significance to CD58 adhesion and transmembrane signaling (23).

\section{CD2-CD58 INTERACTION}

Human peripheral blood $\mathrm{T}$ lymphocytes have sheep red blood cells (SRBC) receptors on their surface. Human T lymphocytes are mixed with SRBC to form a rosette centered on $\mathrm{T}$ cells and surrounded by SRBCs in vitro, known as the "E-rosette test", which reflects the immunological activity of $\mathrm{T}$ lymphocytes (Figure 1B). The formation of E-rosette is dependent on the binding of CD2 in $\mathrm{T}$ lymphocytes with $\mathrm{T} 11$ target structure (T11TS) on SRBC, which is a functionally homologous ligand for CD58 on human erythrocytes $(24,25)$. The anti-CD58 and anti$\mathrm{CD} 2 \mathrm{mAbs}$ can inhibit rosette formation through acting on the erythrocyte and the T lymphocyte, respectively (26). In Hodgkin's lymphoma (HL) tissue, spontaneous rosette formation of T cells with Reed-Sternberg cells is also mediated via CD2-CD58 interaction (26).

The interaction between CD2 in T cells and CD58 in target cells is subtle and unique. Activated human T lymphocytes can form rosettes with autologous erythrocytes, while resting $\mathrm{T}$ cells cannot $(18,27)$. Moreover, the interaction of CD2-CD58 is enthalpydriven, accompanied by adverse entropic changes and energetically remarkable conformational adjustments (28). Unlike the other adhesion, CD2-CD58 interaction does not depend on cellular metabolism and cytoskeletal involvement, insensitive to ambient temperature, and its rate constant and average affinity not influenced by variations in ionic strength such as extracellular $\mathrm{Mg}^{2+} / \mathrm{Ca}^{2+}(26,28)$. 
A

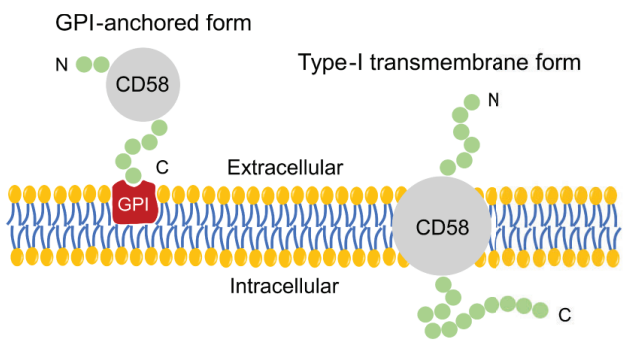

B

FIGURE 2 | Schematic of CD58 isoforms and CD2-CD58 interface. (A) Schematic diagram of two CD58 isoforms, a GPI-anchored and a type-I transmembrane form. (B) Structure diagram of the interface in CD2-CD58, which is mainly supported by electrostatic complementarity instead of shape matching.

\section{STRUCTURE OF INTERFACE IN CD2-CD58}

There are four discrete epitopes on the membrane-distal domain (domain 1) and two overlapping epitopes on the membraneproximal domain (domain 2) in the CD58 molecule (Figure 2B) $(29,30)$. The $\mathrm{N}$-terminus of the CD58 epitopes are functional sites involved in the interaction site with $\mathrm{CD} 2$, while domain 2 connects CD58 to membrane anchor independent of CD2 binding and CD58-mediated activation $(29,30)$. In addition, all epitopes exist in the same numbers on a wide variety of CD58-positive cells and show a uniform trend of increase/decrease after cell activation or malignant transformation (30). Protein-protein interface interactions are fundamentally supported by shape matching and electrostatic complementarity. The crystal structure between the binding interface of CD2 and CD58 is an orthogonal, asymmetric, and face-to-face interaction involving the main $\beta$ sheets of the respective $\mathrm{N}$-terminal domains (31). The binding domain of CD58 is a localized and densely charged surface region on the AGFCC'C" face of the CD2 adhesion site (32). Through disrupting the highly acidic surface of the AGFCC'C" $\beta$-sheet of CD58, it was unexpectedly found that the CD2-CD58 interface lacks significant shape complementarity (33). The electrostatic potential on the CD2 surface is primarily positive because of arginine and lysine residues, whereas CD58 exhibits negative charge at the interface with CD2 due to the presence of glutamate and aspartate residues (Figure 2B) (34). Specifically, the CD2-CD58 binding site is composed of $\beta$-strands $\mathrm{C}$ and $\mathrm{F}$ with charged residues (34). Therefore, electrostatic attraction, rather than shape complementarity, plays a dominant role in the binding of CD2 to CD58 (35). This pattern of binding and recognition is strikingly different from the well-known interactions of other proteins, e.g., antibody-receptor or cytokine-cytokine receptor interactions (33). Under conditions of little hydrophobicity, the interlaced, charged amino acid side chains shape salt and hydrogen bonds at the interface, generating a high degree of specificity despite with low affinity that weaker than initial expectation, which satisfies the special requirements for such interaction to be easily reversible $(36,37)$. Selective binding, weak, reversible, these features are particularly suitable for CD2CD58 interaction to initiate and sustain dynamic bindings between $\mathrm{T} / \mathrm{NK}$ cells and target cells $(36,37)$. In addition, structural analysis shows that CD2-CD58 adhesion has strong conformational flexibility and some unnatural helical conformations under organic solvents or high-temperature conditions (38). The conformational state of the adhesion proteins is beneficial to the modulation of CD2 folding and cell adhesion (38).

As a costimulatory pathway, CD2-CD58 interactions provide a series of favorable conditions for signal recognition of T/NK cells with their targets. Firstly, substantial CD2-CD58 interactions contribute to overcoming intercellular charge repulsion, thereby eliminating bond strain on the interactions of TCR-ligand (39). Secondly, on account of the membrane gap of the CD2-CD58 complex is equal to that of the TCR peptide-MHC complex, numerous CD2-CD58 interactions would place the distance between T/NK cell and target cell within an optimal range for the $\mathrm{T} / \mathrm{NK}$ cell receptor-ligand interaction (40). Thirdly, the cytoplasmic 
domain of CD2 is large and conserved, which facilitates the recruitment of cytoskeleton and signaling molecules into the contact cap (41-43).

Additionally, glycosylation plays a crucial role in intercellular adhesion and regulates the stability and dynamics of proteins in a subtle way (44), which is likewise involved in the regulation of human CD2/CD58-mediated cell-cell adhesion by conformational adjustment (45). Fully glycosylated CD58 is more effective in suppressing the formation of E-rosette than the deglycosylated form, so the maintenance of CD58 glycosylation is essential for the exertion of its functional activity (46). The CD2-CD58 interaction is largely administrated by three hot spots forming a binding triangle, the topology of which is fundamental for the stability of CD2-CD58 binding. The topology of CD2 conformation is remarkably tuned and induced by glycosylation into a specific structure to energetically stabilizes the CD2-CD58 complex. Therefore, CD2 glycosylation facilitates CD2-CD58 binding via conformational adjustment (45).

According to the relevant structure epitopes, drugs or agents are designed to influence CD2/CD58-mediated intercellular adhesion to regulate the immune response. In the CD2-CD58 interface, CD58 Lys34 and CD2 Tyr86 residues are functional hot spots (47). Therefore, short peptide drugs can be constructed from the hot spot $\beta$-strand area of CD2 molecule with CD58 binding site. For example, structural constraints from CD2 are inserted into the peptides via the dibenzofuran moiety to nucleate $\beta$-strand conformation in the peptides, thus regulating the binding of CD2 to CD58 (48). In the collagen-induced arthritis (CIA) mouse model, a peptidomimetic designed to disrupt the interface of CD2-CD58 interaction can inhibit the T/NK cell-mediated immune response through interfering with the binding of CD2 with CD58 (49). Besides, a kind of nonimmunogenic compound 7 is successfully synthesized to act as a lead compound for immunoregulation, accompanied by a reduction of IFN- $\gamma$ and anti-collagen antibody levels in the CIA model, and thus it may be an effective therapeutic drug for the autoimmune disease (50). These results indicate that peptides targeting costimulatory molecule CD2/CD58 can be used to regulate immune responses and contribute to the development of therapeutic drugs for autoimmune and inflammatory diseases.

Previously published studies have demonstrated that using the CD58 fusion protein Alefacept to disrupt the CD2-CD58 interaction can inhibit $\mathrm{T}$ cell activation (51). More importantly, it was found that alefacept could specifically eliminate effector memory $\mathrm{T}$ cells in the peripheral blood and attenuate clinical symptoms in type-I diabetes and psoriasis $(52,53)$. Although the constructed peptides have biological activities in vitro and in vivo, their stability in vivo has limitations as most other peptides (54). Sable et al. adopted a novel approach to reinforce its stability via integrating the CD2 adhesion domain sequence from peptide 6 into the framework of rhesus theta defensins and sunflower trypsin inhibitor (55). The constructed cyclic peptides exhibit potent resistance toward enzymatic degradation and thermal denaturation. Among them, SFTI-a possesses a strong inhibitory activity of cell adhesion in the low nanomolar range to repress $\mathrm{T}$ cell-mediated immune responses from humanized arthritic mice (55).

\section{SOLUBLE CD58}

It was first discovered in 1993 by Hoffmann et al. that the presence of a soluble form of CD58 in human serum, urine, and cell supernatant in vitro (29). At high concentrations, sCD58 can bind to CD2-positive cells and restrain rosette formation of human T cells with sheep and human erythrocytes (29). The mixed lymphocyte reaction could also be profoundly dampened by sCD58 (46). Therefore, local release of large amounts of native sCD58 may disturb cell-cell adhesion and recognition in vivo. Besides, similar to suppression by CD58 mAbs, sCD58 alleviates the cytotoxicity of human $\mathrm{NK}$ clones $\left(\mathrm{CD} 2^{+} \mathrm{CD} 3^{-}\right)$. In contrast, sCD58 and mitotic CD2R mAb act synergistically in the triggering of $\mathrm{T}$ cell activation (46). These findings reveal that sCD58 modulates intercellular adhesion and T/NK cell-mediated immune responses by acting as a biological immunoregulator.

It has been shown that sCD58 can curb the lysis of neoplastic cells through competitively suppressing the binding to CD2. The release of substantial sCD58 from melanoma cells results in their accumulation within the tumor tissue at high concentrations sufficient to inhibit cellular immune responses and immunotherapeutic sensitivity (56). Hollander et al. found sCD58 was constitutively secreted into the supernatant of human B lymphoblastoid cells and the GPI-deficient mutant cells generated more sCD58 than wild-type cells (57). A similar phenomenon can be observed in lymphocytes from patients with paroxysmal nocturnal hemoglobinuria (PNH), which is characterized by a defect in the GPI-anchoring pathway. Therefore, lymphocytes in $\mathrm{PNH}$ patients generate more sCD58 than normal cells as the absence of GPI anchoring (58).

Although alternative splicing, direct secretion, and proteolytic shedding have not yet been corroborated as possible mechanisms of $\mathrm{sCD} 58$ production, the $\mathrm{sCD} 58$ release is likely to be derived from enzymatic cleavage of membrane-anchored CD58, since lack of a distinct mRNA for sCD58 and the downregulation of CD58 surface expression is always accompanied by the accumulation of sCD58 in the cellular supernatant (58-60). Furthermore, subsequent studies have revealed that the expression of surface CD58 is decreased following the treatment of PI-specific phospholipase C (PI-PLC) (61). Those changes between membranous CD58 and sCD58 may significantly affect adhesion/deadhesion processes, because the CD2-CD58 axis is one of the dominant pathways to mediate the interaction between T/NK cells and other cells $(62,63)$. Thus, cleavage of membranous CD58 may be responsible for the production of its soluble form, which plays a crucial role in the deadhesion of T/NK cells with target cells.

Regarding the immune function of sCD58, it was found that the dimeric and multimeric forms of synthetic sCD58 have a stronger potency than the monomeric biological form. The dimeric sCD58 inhibits antigen-stimulated proliferation of $\mathrm{T}$ lymphocytes to exert its immunosuppressive capacities via inducing regulatory $\mathrm{T}$ cells (64). The multimeric $\mathrm{SCD} 58$ is more effective than the monomer in refraining the proliferation of $\mathrm{T}$ lymphocytes in response to allogeneic cells, tetanus toxoid, or purified protein derivative (65). This inhibitory effect is not only due to physical blockage of intercellular interactions, but may also 
involve negative signaling generated via multimeric sCD58-CD2 interactions (65). Accordingly, it owns a strong potential as an immunomodulatory agent to suppress antigen-specific $\mathrm{T}$ cell responses for the treatment of inflammatory and autoimmune diseases. So far, the role of SCD58 in the tumor microenvironment has not been explored. With regard to the potential competitive inhibition of sCD58 between T/NK cells and target cells, sCD58 may be involved in cancer cell-induced immunosuppression, which has potential clinical implications and needs to be further mined and demonstrated.

\section{EFFECTS OF CYTOKINES AND DRUGS ON CD58 EXPRESSION}

The regulation of CD58 expression by cytokines is cell-dependent. In colonic epithelial cells, breast cancer cells and normal hepatocytic cells, the expression of CD58 is unresponsive to cytokine stimulation, including TNF- $\alpha$, IFN- $\gamma$, IL-1, and IL-6 (66-68). There was no change in CD58 expression after stimulation of bronchial epithelial cells with TNF- $\alpha$ or IFN- $\gamma$ (69). Similarly, TNF- $\alpha$ and IFN- $\gamma$ do not influence the expression of CD58 in embryonic brain astrocytes (70). In contrast, the expression of CD58 was sensitively increased after incubation with IL-4 in human B-lymphoma cells and Burkitt's lymphoma cell lines (68, $71,72)$. Stimulation of cultured leukemic blasts with TNF- $\alpha$ increases CD58 expression, in turn facilitating susceptibility to lymphocyte-mediated lysis (73). After exposure to GM-CSF, CD58 expression is significantly upregulated in acute myelogenous leukemia (AML) cells (74). Besides, ultraviolet (UV)-B irradiation decreases the expression of CD58 on EpsteinBarr virus (EBV)-transformed B cells (75).

Notably, CD58 expression is significantly affected by some exogenous stimuli or drugs. The expression of CD58 on the surface of hepatocellular carcinoma (HCC) cells is dramatically elevated after anisomycin treatment and blockade of CD58 can potently impair the anisomycin-mediated enhancement of $\mathrm{NK}$ cytotoxicity (76). Thus, the adhesion molecule CD58 is likely to be critical for NK-mediated immunotherapy (76). Furthermore, $\beta$-interferon can significantly enhance the proportion of CD58 positive endothelial cells (77). All-trans retinoic acid (ATRA) and dexamethasone robustly diminish the surface expression of CD58 in vitro, which probably explains the efficacy of these drugs in treating inflammation-related diseases in vivo to some extent (78, 79). Moreover, long-term lead exposure reduces the expression of the erythrocyte adhesion molecule CD58, weakening the sensitivity to IFN- $\gamma$, in preschool children (80).

The surface CD58 appears to be unresponsive to cytokines, but the production of sCD58 is relatively sensitive to cytokines such as IL- $1 \beta$, IFN- $\gamma$, and TNF- $\alpha$. Albeit this, the generation of sCD58 varies from cell to cell, as demonstrated by its release from some, but not all, tumor cell lines. The sCD58 is only released in 6 out of 10 melanoma cell lines. Among them, sCD58 production can be potently affected by IFN- $\gamma$ in all lines and by TNF- $\alpha$ in one (56). The sCD58 in the adenocarcinoma cell supernatant can be detected only after IL-1 $\beta$ stimulation (29).
Both PMA and TNF- $\alpha$ can augment the release of sCD58 in HCC cells, but the production of sCD58 is unaffected following IL-1 $\beta$ stimulation (29). Thus, different cells exhibit different susceptibility to TNF- $\alpha$ and IFN- $\gamma(29,56)$. This regulation is cell-specific, especially IFN- $\gamma$, which inhibits the release of sCD58 in larynx epidermoid carcinoma cells but promotes the production of the soluble form in lung epidermoid carcinoma cells (60). In fact, CD58 is also present in a cytoplasmic "pool" of each cell; meanwhile, cleavage of surface CD58 by PLC can result in an increase of intracellular CD58 (60). Therefore, the cytoplasmic, membranous, and soluble form of CD58 is likely to be interrelated and dynamic. Apart from the expression level of CD58, activation status, secretory activity, and endogenous protein sheddase levels may be the major reasons for the celldependent differences in the production of sCD58 (60).

\section{CD2/CD58/CD48/CD59}

CD2, CD48, CD58, and CD59 are tightly associated members of the immunoglobulin superfamily and they have similar structures in extracellular regions (81). CD58 is the primary natural ligand for human CD2; CD48 and CD59 are two additional, low-affinity ligands for human $\mathrm{CD} 2$, and their interactions in the human are limited and independent of glycosylation $(82,83)$.

The CD2 binding sites with CD58 and CD59 are overlapping, but not exactly identical (84). In murine $\mathrm{T}$ cell hybridomas expressing human CD2, anti-CD59 mAbs suppress CD2mediated $\mathrm{T}$ cell activation, indicating that direct interaction of CD2 with CD59 likewise facilitates $\mathrm{T}$ cell-specific immune responses (84). Thus, CD59 is considered as the second ligand for CD2 and synergizes with CD58 to promote the adhesion and activation of $\mathrm{T}$ lymphocytes $(85,86)$. Notably, CD59 promotes CD58-mediated T cell proliferation and IL-2 production, whereas in the absence of CD2-CD58 interaction, the CD59 molecule itself cannot stimulate $\mathrm{T}$ cell proliferation alone even in the presence of exogenous recombinant cytokines such as IL-1, IL-6 (82).

Although CD58 is distributed on a wide range of human cells and tissues, the CD58 gene has not yet been found in murine, and the only counter-receptor for CD2 identified heretofore is CD48 (87). CD48 is considered to be a homologue of human CD58 in murine since its high similarities in distribution and structure (88). Arulanandam et al. surmise that CD58 may have evolved at the later stage of mammalian evolution due to gene duplication from CD48 to become an exclusive counter-receptor for CD2 after divergence from murine (89-91). The speciesspecific differences in the CD2/CD58/CD48/CD59 system are summarized in Figure 3A (91).

In humans, $\mathrm{T} / \mathrm{NK}$ cell adhesion molecule CD2 interacts with diverse ligands, such as CD58, CD48, CD59, and even the novel carbohydrate structure (92). However, there is no additional ligand for the adhesion pair of CD2-CD48 in murine (93). The interaction affinity of mouse CD2-CD48 is lower than that of human CD2-CD58. Murine CD48 is also involved in the modulation of $\mathrm{T}$ cell activation, and CD48 binds to the T11 (1) region of $\mathrm{CD} 2$, the identical area of $\mathrm{CD} 2$ interacts with $\mathrm{CD} 58$ 
(94). Application of anti-CD48 mAb can effectively restrain not only weak, hapten-specific responses, but also strong, alloantigen-specific responses of cytotoxic $\mathrm{T}$ lymphocytes (CTLs) in vivo (95). Besides, anti-CD48 mAb interferes with $\mathrm{CD} 4^{+}$-dependent pathways in vivo, and the maximal effect of it concentrates on the immune efferent stage (95). Of note, combined administration of CD48 with CD2 mAbs cannot heighten the immunosuppressive effect generated by CD2 mAb alone, indicating that regulation of the $\mathrm{CD} 2$ receptor, rather than a disturbance of the CD2-CD48 interaction, is the primary effect of CD2-mediated immunosuppression in the murine (96).

\section{IMMUNOLOGICAL SYNAPSE}

After successful recognition of APCs by T cells, a specialized nanoscale structure is formed in the contact area through cytoskeletal remodeling and receptor rearrangement, known as the IS (97). Specifically, the IS consists of three layers of supramolecular activation complexes (SMAC), classified into central, peripheral, and distal SMAC (c, p and dSMAC, respectively) (98). The CD2-CD58 interactions are important components of the IS and contribute to the maintenance of high intracellular calcium levels (99). In addition to localizing to cSMAC together with other molecules, including CD28/CD80/ 86 and TCR-peptide-MHC complexes, the clusters of CD2CD58 complexes also shape a ring-like framework between pSMAC and dSMAC at the outer edge of the mature IS, termed "corolla" (Figure 1C) (100). The corolla amplifies the activity of p-SFK/LAT/PLC- $\gamma$ superior to TCR alone. The CD2-
CD58 interactions in corollas are more signal-enhancing than central CD2-CD58 interactions. The corolla boosts CD2dependent amplification of TCR signaling but can be buffered by PD-1 invaded the corolla (101). Chimeric antigen receptor (CAR) T-cell transfer is a novel and promising approach of adoptive $\mathrm{T}$-cell immunotherapy in tumors. When in contact with the target cancer cell, CAR-T cell form an important IS with cancer cell, in turn dynamically coordinating multifarious forces to execute its cytotoxic function (102). Strategies to assist CART-mediated IS with tumor cells by strengthening CD2-CD58 interaction may be beneficial for cancer immunotherapy.

\section{CD2-CD58 IN T CELLS}

$\mathrm{T}$ cell activation results in increased CD2 surface expression, affinity, and lateral mobility, allowing the CD2 molecules to diffuse from the lateral area into the contact interface and engage CD58 $(103,104)$. Afterwards, this process causes the CD2 that binds CD58 to be recognized and immobilized at the region of intercellular contact via $\mathrm{CD} 2$ conformational change, thus elevating the number of CD2-CD58 ligations and strengthening adhesion (103). This pattern combines passive diffusion with active recognition of conformational alteration to potentiate intercellular adhesion by CD2-CD58 interactions (Figure 3B).

In the absence of costimulatory signaling, stimulation of $\mathrm{T}$ cells by TCR/CD3 alone results in T cell anergy (105), thus the activation of $\mathrm{T}$ lymphocytes requires at least two signals. The first signal provided by ligation of the TCR with a specific MHC, and the second signal involves the ligand-receptor pair interactions of
A

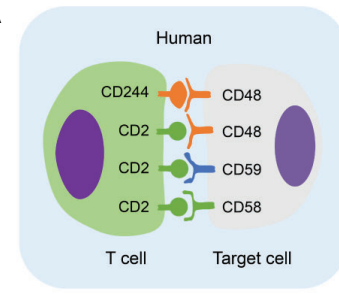

B

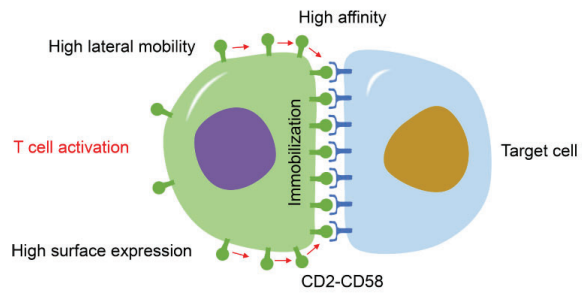

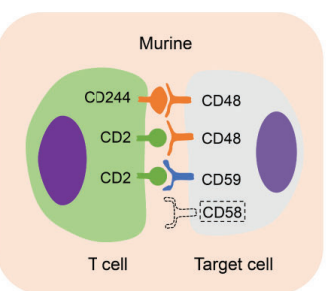

C

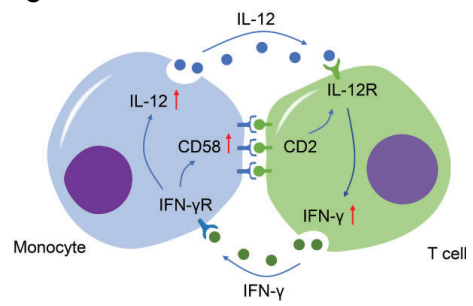

FIGURE 3 | Schematic diagram regarding CD2/CD58/CD48/CD59 system, CD2-CD58 immobilization in T cell activation, and IL-12/IFN- $\gamma$ feedback loop. (A) Specific differences of reciprocal adhesion molecule between human and murine in the CD2/CD58/CD48/CD59 system. CD2 and CD244 (2B4) are presented at the surface of T/NK cells in human and murine. Specifically, CD2-CD58 is the principal ligand-receptor pair. CD48 and CD59 are two additional and low-affinity ligands of CD2 in human. The CD48 receptor binds both CD2 and CD244, while the CD58 gene is absent in murine. (B) The immobilization of CD2-CD58 following T cell activation. This process consists of three important features, increased CD2 surface expression, the high affinity of CD2-CD58, and rapidly lateral mobility; a series of conformational changes is beneficial to strengthen intercellular adhesion and aid recognition. (C) The important role of CD2-CD58 interaction in the IL-12/IFN- $\gamma$ positive feedback loop between monocytes and activated T cells. 
costimulatory adhesion (106-108). CD2 is one of the most important adhesive receptors presented on almost all of $\mathrm{T}$ lymphocytes and it offers costimulatory signal after interacting with CD58 on target cells $(12,109)$. The purified CD58 possesses a clearly mitogenic effect for human resting $\mathrm{T}$ lymphocytes (110). The anti-CD2 and anti-CD58 mAbs induce $\mathrm{T}$ cell unresponsiveness to mitogenic or antigenic stimuli and inhibit CTL-mediated killing by binding to the $\mathrm{T}$ cells and target cells, respectively (111). These results reveal the critical role of the CD2-CD58 interaction in T cell stimulation.

Although the CD2 engagement by CD58 alone is not sufficient for $\mathrm{T}$ cell activation (111-113), the CD2-CD58 interaction without other stimuli can still trigger intracellular biochemical alterations, that is, modulation of $\mathrm{T}$ cell function by inducing remarkable, transient upregulation of intracellular cAMP concentration (114). In the absence of TCR stimulation, CD58-bound CD2 induces signaling into microdomains via the actin-dependent aggregation of signaling molecules, such as LAT, Lck, and TCR- $\zeta$ chain (115). When stimulated together, TCR and CD2 were separated to different regions after transient colocalization in small microdomains; this spatial segregation is likely to allow the two receptors to synergistically strengthen signal transduction (115). Both receptors with different structures induce a fast spatial reconstruction of molecules in the cell membrane, indicating a pattern that local accumulation of signaling molecules initiates T cell signaling (115). Moreover, CD2-CD58 interaction renders the generation of a close adhesion zone between $\mathrm{T}$ cell and APC, in which the binding of TCR to peptide-MHC complexes is potentiated (116). TCR drives PLC $\gamma 1$ phosphorylation and increases the enzymatic activity of PLC $\gamma 1$, resulting in phosphoinositide cleavage and continuous $\mathrm{Ca}_{2}^{+}$mobilization, which is necessary for $\mathrm{T}$ cell proliferation and cytokine production $(117,118)$. The CD2CD58 interaction is able to maintain and reinforce antigenmediated $\mathrm{Ca}_{2}{ }^{+}$influx in $\mathrm{T}$ lymphocytes interacting with APCs. CD2 and TCR is synergistic, and their signals converge to activate the PLC $\gamma 1 / \mathrm{Ca}^{+}$pathway at the IS (99).

The costimulatory signaling of CD58 activates CTLs to proliferation, cytotoxicity, and cytokine secretion, including IFN- $\gamma$, TNF, and IL-2 (119). IL-2 is the main T cell growth factor transcribed in resting $\mathrm{T}$ lymphocytes (120). As an important secondary signal of $\mathrm{T}$ cell activation in response to CD58-positive antigen-bearing stimulator cells, CD2-CD58 signaling induces IL-2 secretion through influencing nuclear factor (NF)-mediated the transcription of the IL-2 promoterenhancer $(121,122)$, which maintains autocrine $\mathrm{T}$ cell growth and the generation of IFN and TNF (123). Furthermore, in the presence of CD58-like signals, such as human $\mathrm{rCD} 58, \mathrm{~T}$ cell responsiveness to both IL- 6 and IL- 1 is promoted by CD2-CD58 interaction, suggesting it exerts a significant function in T cell/ monocyte interactions during the initial immune responses via increasing $\mathrm{T}$ cell sensitivity to monocyte-secreted cytokines (124). Costimulation of T lymphocytes by CD58 effectively facilitates IFN- $\gamma$ and IL-10 secretion in a calcineurindependent manner, and both IFN- $\alpha$ and IL-12 can further increase CD58-mediated IL-10 secretion (125). In contrast,
TNF- $\alpha$, IL-2, IL-4, IL-5, IL-13 production is low or even absent following CD58 costimulation, which was not an inhibitory effect of endogenously produced IL-10 (125). Furthermore, $\mathrm{T}$ regulatory cells (Tregs) are relatively poor in terms of mediation of Th1/Th2 immune responses, secretion of IL-10, and proliferation responses in vivo (126). CD2-CD58 interaction can induce the of non-proliferative Tregs with the production of large quantities of IL-10. This effect is unique to CD2 signaling since it is not acquired or even suppressed via mobilizing other costimulatory (127).

Of note, the CD2-CD58 interaction can particularly improve the T lymphocyte response to IL-12, which possesses a series of immunoregulatory effects on activated T/NK cells, like proliferation stimulation, IFN- $\gamma$ secretion, and cytotoxicity (128). IL-12 responsiveness to APC-depleted T lymphocytes is restored by the Chinese hamster ovary $(\mathrm{CHO})$ cells expressing CD58 (129). More importantly, the CD2-CD58 interaction offers the central functional connection in the IL-12/IFN- $\gamma$ positive feedback loop between monocytes and activated $\mathrm{T}$ cells (Figure 3C) (130). During antigen presentation, a sufficient number of CD58 molecules on monocytes bind to the aminoterminal domain of CD2 on T cells. Relating intracellular signals by CD2 subsequently generates and initiates optimal $\mathrm{T}$ cell responsiveness to IL-12 (131). Monocyte-secreted IL-12 induces Th1 differentiation and significantly increases cytokine secretion, including IL- 2 and IFN- $\gamma$ (129). In turn, T cell-derived IFN- $\gamma$ motivates monocytes to produce IL-12 and boosts the expression of CD58 in monocytes, thus further strengthening $\mathrm{CD} 2$-mediated signaling and maintaining $\mathrm{T}$ cell responsiveness to IL-12 (131). Moreover, IFN- $\gamma$ provokes monocyte to kill the intracellular pathogen, whereas IL-12 and IL-2 facilitate nonMHC-restricted NK cell killing. Therefore, the CD2-CD58 interaction may be regarded as an important part of innate and acquired immune responses.

One of the most important factors causing activation-induced cell death (AICD) of T cells, an essential sustainer for lymphoid homeostasis, is triggered by the ligation of Fas (Fas-L) (132). Fas-induced AICD of activated T cells is effectively protected by dendritic cells (DC) in a CD58-dependent fashion (133). More importantly, CD2-CD58 interaction potently refrains the apoptosis of $\mathrm{T}$ cells through blocking the CD3-mediated Fas/Fas-L upregulation (134). CD58 costimulation increases the number of effective nuclear NF-ATp and maximizes the induction of NF-AT complexes, implying CD2-CD58 signaling is implicated in the regulation of NF-AT translocation from cytosol to nucleus (122). In addition, costimulation of CD2-CD58 on primary $\mathrm{T}$ cells results in STAT1 phosphorylation and nuclear translocation (135). Notably, cytokine-driven STAT phosphorylation is usually transient, whereas STAT1 phosphorylation upon CD2-CD58 stimulation can sustain several days. Transcription of pivotal target genes, including c-fos and IRF1, undergoes prolonged and delayed effects after CD2 stimulation, hinting that the special model of STAT activation may incur a unique cellular response following CD2 stimulation by CD58. Interestingly, this signaling seems to be exclusive to T cells, CD2 stimulation on NK cells cannot evoke STAT1 phosphorylation (135). 
A small fraction of human $\mathrm{CD}^{+} \mathrm{T}$ cells are known to coexpress CD56 (136), an antigen generally restricted to NK cell expression. It has been demonstrated that $\mathrm{CD}^{+} \mathrm{CD}^{+} 6^{+} \mathrm{T}$ cells have strong MHC-unrestricted cytotoxicity against neoplastic cells in vitro and in vivo (137). The CD2-CD58 interaction precisely provides the strong activation signals for expansion and differentiation of $\mathrm{CD}^{+} \mathrm{CD}^{+} 6^{+} \mathrm{T}$ cells (138). In adults, a considerable proportion of $\mathrm{CD}^{+} \mathrm{T}$ lymphocytes lack the expression of $\mathrm{CD} 28$, which is one of the characteristics of $\mathrm{T}$ cell senescence, meaning a low proliferative capacity and functional impairment (139). The majority of costimulators have a low ability to activate CD28-deficient T cells, while the CD2-CD58 interaction strongly induces the proliferation and cytokine production, as well as enlarges TCR signals in CD28$\mathrm{CD}^{+} \mathrm{T}$ cells (140). Blocking CD58 significantly dampens the response of $\mathrm{CD} 28^{-} \mathrm{CD} 8^{+} \mathrm{T}$ cells to allogeneic $\mathrm{DCs}$ and viral antigens (140). These results reveal that CD2-CD58 signal is an important costimulatory pathway to facilitate the control of chronic infection by maintaining the persistent expansion of CD28 ${ }^{-} \mathrm{CD}^{+} \mathrm{T}$ cells.

Apart from T/NK-mediated cellular immunity, it is worth noting that CD2-CD58 interaction also participates in the immunoregulation of humoral immunity. Recently, the CD2 and CD58 homologs in the model species zebrafish have been identified, which have the same conserved structural characteristics as mammals (141). After antigen stimulation, $\mathrm{CD} 2$ and $\mathrm{CD} 58$ on $\mathrm{CD}^{+} \mathrm{T}$ cells and APCs are increased, respectively. Loss function of $\mathrm{CD} 2$ and $\mathrm{CD} 58$ strikingly restrains the activation of $\mathrm{mIgM}^{+} \mathrm{B}$ cells and antigen-specific $\mathrm{CD} 4^{+} \mathrm{T}$ cells, and subsequently suppresses the production of antibody and host defense against pathogens. The CD2-CD58 interaction offers a major costimulatory signal for the sufficient activation of $\mathrm{CD}^{+}$Th-mediated adaptive humoral immunity in zebrafish (141). Given the absence of CD58 in rodents, zebrafish is anticipated to serve as an animal model for immunological research to make up for the shortcomings of mouse models.

\section{CD58 IN THYMOCYTE DEVELOPMENT}

During the differentiation and development of thymocytes, CD2 is one of the earliest molecules expressed; its surface density gradually reduces as thymic maturation (7). The CD2-CD58 interactions influence the affinity between TCR and peptideMHC at the stage of positive and negative selection, which confers the ability of immature thymocytes to resist the high affinity of TCR-pMHCs to escape negative selection (100). Thymocyte proliferation needs the induction of CD58-positive L cells and phytohemagglutinin (PHA), which could be repressed by CD2 or CD58 mAb (142). Receptors for CD2 antigens situated on reticular epithelial cells, which can initiate the induction of proliferative wave of immature cortical thymocytes through interacting with the CD58 molecule (143). The anti-CD2 and anti-CD58 mAbs impede the binding of thymocyte with thymic epithelial cells, and thus suppress thymocyte activation in thymic epithelial cell-dependent manner, meaning that the natural ligand CD58 presented on human thymic epithelial cells contributes to the $\mathrm{T}$ cell mature and activation via the CD2 molecule $(62,144)$. Collectively, these results outline a crucial role for the CD2-CD58 pathway in T cell maturation and thymic differentiation.

\section{CD58 IN NK CELLS}

At a study of the mechanism that NK-mediated cytotoxicity to breast cancer targets, unexpectedly, anti-CD58 mAb failed to inhibit NK-mediated killing but instead mediated the enhanced cytotoxicity associated with CD58 expression, albeit CD2 blockade mildly reduced cytotoxicity (145). These results indicate NK-mediated cell lysis of breast cancer is potentiated through antibody-dependent cellular cytotoxicity (ADCC) against CD58. More importantly, CD2-CD58 interaction exerts an important function in cytotoxic function and membrane nanotube formation between NK cells and target cells (146), which is a wafery membranous protrusion physically linked two cells and able to perform substantial functions including assisting in cell-to-cell communication (147). It reveals a special role for CD2-CD58 in allowing NK cells to explore the local microenvironment through facilitating nanotube formation.

Notably, CD58 is also expressed in NK cells. Freshly isolated NK cells from human peripheral blood are consistently CD58positive and activated NK cells with IL-2 in vitro results in an approximately 5-fold increase in surface expression of CD58 $(148,149)$. Therefore, CD58 appears to exert dual or even multiple functions. However, the exact function of CD58 on NK cells to date is still unclear. Future research should focus on this issue and investigate the functional differences of CD58 in immune cells and target cells, which is critical for therapeutic applications.

\section{CD58 IN OTHER IMMUNE CELLS}

The surface of memory T cells express high levels of CD58, which has an important role in improving their responsiveness, and the $\mathrm{CD}_{5} 8^{+}$subgroup generates more IFN- $\gamma$ than the CD58 subgroup following PHA stimulation (150). In terms of DCs, the significant role of the CD2-CD58 interaction in DCs is to enable immune and non-immune cells to directly interact with DCs, triggering innate and adaptive immune responses (151). Besides, CD2-CD58 interaction has been reported to participate in $\mathrm{B}$ cell differentiation by interacting with $\mathrm{T}$ cells and monocytes to some extent, but not in its proliferation (152). The binding of CD2 with CD58 located on the surface of autologous erythrocytes increases $B$ cell responses to mitogens and antigens (153). Antibodies against CD58 can induce IgE secretion in IL-4-activated B cells (154). Thus, CD2-CD58 stimulation provides alternative signaling to modulate $\operatorname{IgE}$ production through intercellular contact interaction. 


\section{CD58 IN ENDOTHELIAL CELLS}

CD58 molecule plays a critical role in the interactions between $\mathrm{T}$ cells and ECs. Early costimulation by EC facilitates lipid raft clustering in a CD2-CD58 dependent manner, resulting in the enhancement of TCR-triggered pathways (155). Human ECs increase the expression level of CD40 ligand, a vital receptor mediating $\mathrm{T}$ cell activation, in activated $\mathrm{CD} 4^{+} \mathrm{T}$ cells via $\mathrm{CD} 58$ induced mRNA stabilization $(156,157)$. Furthermore, CD58 can fuel $\mathrm{T}$ cell adhesion to EC, facilitating the recruitment of circulating $\mathrm{T}$ lymphocytes into the inflammation site in vivo (158). The blockade of CD58 dampens T cell-mediated cytotoxicity to allogeneic EC and impairs IL-2 transcription and cytokine synthesis of EC (159-161). Activated T cells can enhance the permeability of ECs by the CD2-CD58 interaction (162).

\section{CD58 IN INTESTINAL EPITHELIAL CELLS}

It has been found that CD58 is expressed constitutively in the native IEC and IEC lines. Anti-CD58 mAb suppresses IEC-mediated proliferation of $\mathrm{CD}^{+} \mathrm{T}$ cells (163). Specifically, CD58 molecules are highly polarized and confined to the basolateral surface of the IECs in a topological fashion at the contact area of $\mathrm{T}$ cells, and act as a costimulator in HLA class II-mediated antigen presentation (163). Moreover, intestinal $\mathrm{CD}^{+} \mathrm{TCR} \alpha \beta^{+} \mathrm{CD}^{+}$intraepithelial lymphocytes (IEL) are strongly linked to IECs and CD2-CD58 interaction participates in their crosstalking. Concretely, IELs are stimulated via interacting with IECs by the CD2-CD58 pathway and this process promotes the synergistic synthesis of IL-8, leading to the TNF- $\alpha$ release, which in turn increases IL- 8 production and CD58 expression by the IECs (164).

\section{CD58 POLYMORPHISMS}

It has reported that CD58 single-nucleotide polymorphisms (SNP), including 6 variations, rs12044852A/C (SNP1), rs2300747A/G (SNP2), rs1335532C/T (SNP3), rs1016140G/T (SNP4), rs1414275C/T (SNP5) and rs11588376C/T (SNP6), related to the risk of neuromyelitis optica (NMO) (165). For instance, rs1016140 $\mathrm{G}$ allele can enhance $\mathrm{T}$ cell activity and impede the penetration of AQP4 antibody into the central nervous system (CNS), eventually causing NMO progression. The rs2300747 A allele augments NMO risk by reducing the RNA expression of CD58. Furthermore, the percentage of CD58-positive monocytes is markedly lower in healthy controls with each of these risk genotypes of autoimmune thyroid diseases (AITDs), and lower in patients with Graves' disease and Hashimoto's disease, compared to healthy individuals (166). Therefore, CD58 SNPs may participate in AITD susceptibility by decreasing CD58 expression. In a large cohort of candidemia, Kumar et al. analyzed more than 110,000 SNPs at 186 loci known to date to be related to immune-mediated diseases and showed a strong correlation between CD58 SNPs and candidemia (167). Altered level of CD58 not only modulates macrophage phagocytosis, but also indirectly affects cytokine production. For example, the SNP rs17035850 of CD58 is relevant in persistent fungemia, a positive blood culture lasted for 45 days albeit sufficient treatment, whereas the SNP rs12025416 of CD58 is linked to lower levels of Candida stimulated TNF- $\alpha$ and IL-6 (167).

\section{MULTIPLE SCLEROSIS}

MS is a genetically complicated autoimmune disease in the CNS. Many published studies have illustrated that CD58 SNPs such as rs12044852 and rs2300747 are tightly related to MS risk in different populations, including European Caucasian, Iranian, Russians (168-172). A recent study found that carriers of the MS risk allele rs1414273 exhibited decreased CD58 mRNA levels but elevated miR-548ac levels through analyzing diverse datasets from global populations (173). In particular, SNP rs1414273 is localized at the miR-548ac stem-loop site of CD58 first intron, which can regulate the cleavage activity of Drosha, thus propelling expression uncoupling between CD58 and miR548 ac from a common original transcript in immune cells (173). Additional evidence for the role of CD58 in MS susceptibility reveals that CD58 expression is reduced in the cerebrospinal fluid of patients with MS (174). Genome-wide association scans demonstrated that CD58 allelic variants were linked to the risk of developing MS via analyzing more than five thousand MS patients (170). The CD58 protective allele (rs2300747) of MS exerts its function on disease risk through elevating CD58 mRNA expression in a dose-dependent fashion in circulating mononuclear cells and lymphoblastic cells from MS patients during clinical remission (170). Mechanistically, protective allele-induced CD58 accumulation increases the expression of the transcription factor FoxP3 via CD2-CD58 interaction, potentiating the function of $\mathrm{CD} 44^{+} \mathrm{CD} 25^{\text {high }}$ Tregs that are defective in MS (170). Moreover, the protective allele of rs1335532 is associated with MS and is located in the active enhancer region of the CD58 gene, generating a strong functional binding site of Ascl2, which induces activation of the CD58 promoter via the Wnt pathway in monocytes and lymphoblasts (175). Notably, the Alu insertion facilitates skipping of CD58 exon 3 and drives a frameshifted transcript, suggesting that Alu polymorphism is perhaps a causative factor for elevated MS risk (176).

\section{CHRONIC HEPATITIS}

The expression of CD58 in hepatocytes of chronic hepatitis exhibits cytoplasmic and membranous staining and elevated with the severity of chronic HBV infection, the degree of inflammatory activity, and liver damage (177-179). More importantly, the proportion of $\mathrm{CD} 58^{+}$cells in peripheral blood mononuclear cells and the levels of SCD58 in serum of patients with $\mathrm{HBV}$ infection are conspicuously higher than that in the healthy individuals and positively associated with serum levels of AST and ALT $(178,179)$. These findings demonstrate that CD2-CD58 
interactions between lymphocytes and hepatocytes exert an essential function in chronic hepatitis (177). Immune adhesion molecule CD58 may strengthen viral elimination via activating T/NK cells and stimulating the cytotoxic immune response. Unfortunately, this also causes the damage of hepatocytes (179).

\section{RHEUMATOID ARTHRITIS}

The level of CD58 in chondrocytes is higher in arthritic joints than in normal joints; CD58 expression is higher on synovial fluid lymphocytes of RA in comparison with peripheral blood lymphocytes from RA patients or healthy individuals (180). The expression of sCD58 in synovial fluids and serum from patients with RA are remarkably diminished in contrast with that in control subjects and patients with spondyloarthropathy (SpA) or osteoarthritis (OA) (180). Under physiological conditions, the CD2-CD58 interaction could be inhibited by local sCD58 production. Therefore, the insufficient release of sCD58 may lead to accumulation of $\mathrm{T}$ cells and continued inflammation in synovitis due to sCD58-mediated deadhesion (181).

\section{CYTOMEGALOVIRUS INFECTION}

CMV is the main pathogen in AIDS patients and transplant recipients, and the presence of this virus can exacerbate allograft rejection. The surface expression of CD58 augmented after CMV infection in vitro, caused by direct action of virus infection rather than by a secondary induction of cytokine (182). The CD2 interaction with increased CD58 on the surface of CMVinfected cells is a crucial node for antibody-induced activation and NK-mediated cytotoxicity during the antiviral response (183). Blockade of CD2-CD58 interaction causes a reduction in the secretion of TNF- $\alpha$ and IFN- $\gamma$ by adaptive NK cells following $\mathrm{CMV}$ infection. As a virus-encoded downregulation factor of CD58, the CMV glycoprotein UL148 can retain CD58 within the endoplasmic reticulum without being transported to the cell surface, which weakens activation of CTLs and attenuates cellmediated antiviral response (184). Therefore, CD2-CD58 interaction is critical for the recognition and activation between T/NK cells and CMV-infected cells.

\section{INFLAMMATORY BOWEL DISEASE}

Serum levels of sCD58 are profoundly reduced in IBD, including Crohn's disease and ulcerative colitis, relative to healthy controls. Decrease of sCD58 in sera associated with multiple clinical parameters of disease activity, including CDAI score and erythrocyte sedimentation rate (ESR) (185).

\section{TRANSPLANTATION}

Co-expression of CD58 on the stimulator cells elicits significant potentiation of the primary alloresponse and proliferative response of $\mathrm{CD}^{+} \mathrm{T}$ cells (186). In the rat model of heart transplantation, treatment with CD2-targeting mAbs conspicuously prolong rat survival (187). Although anti-CD48 $\mathrm{mAb}$ alone fails to prolong graft survival, anti-CD48 mAb can synergize with anti-CD2 $\mathrm{mAb}$ to induce long-term survival of allograft $(187,188)$. Another xenograft mouse experiment shows that blocking the CD2-CD58 axis effectively prevents human skin allografts from lymphocyte infiltration and inflammation damage (189). Therefore, the CD58 molecule plays a role in lymphocyte-mediated immune rejection, and blockage of CD2-CD58 interaction contributes to alleviating allograft and xenograft responses.

\section{HEMATOLOGICAL MALIGNANCIES}

\section{Acute Lymphoid Leukemia}

In ALL, CD58 expression is negatively related to the percent of peripheral blast cells, leukocytosis, and the presence of a clinical tumoral syndrome (190). Leukemia patients with poor prognosis frequently lack the expression of CD58, while the higher expression of CD58 is strongly associated with longer survival time (191). In addition, $\mathrm{CD}^{+} 8^{+} \mathrm{CD} 58$ - is an independent poor prognostic factor in pediatric patients with $\mathrm{Ph}^{-} \mathrm{B}$-cell ALL, who have shorter survival and higher risk of relapse (192). As nonmalignant B cells differentiate from early to mature stages in the bone marrow, the expression of CD58 gradually reduces, while it is usually upregulated in pediatric and adult B-cell ALL (193). The expression of CD58 is remarkably higher in ALL blasts than that in normal B cells, whereas there is no significant difference between regenerated and normal B cells (194). More importantly, CD58 has high accuracy and stability in minimum residual disease (MRD) detection at different clinical stages, thus CD58 could be used as an effective indicator for monitoring MRD in B-cell progenitor ALL (BCP-ALL) (194, 195). Furthermore, due to the presence of hematogones, it may be difficult to distinguish leukemic lymphoblasts in the diagnosis and follow-up of BCP-ALL. The use of the CD81/CD58 ratio as the discriminating marker enhances the difference between leukemia lymphoblasts and hematogones with high sensitivity and specificity in patients with BCP-ALL (196).

\section{Acute/chronic Myelocytic Leukemia}

In AML, CD58 expression is positively correlated with complete remission rate, overall survival, and disease-free survival (191). Progenitor cells from untreated CML patients exhibit diminished CD58 expression, but surface CD58 expression could be at normal levels or even exceed normal levels after IFN- $\alpha$ treatment (197). CML progenitor cells lacking CD58 cannot activate normal proliferation responses of $\mathrm{T}$ lymphocytes, resulting in abnormal adhesion of CML progenitor cells and abnormal clonal proliferation (197). Transformed cells are generally killed by lymphokine-activated killing (LAK) cells. Anti-CD58 mAb can significantly block the LAK cell lysis, indicating the loss of CD58 in CML may be an important cause of LAK resistance (198). 


\section{LYMPHOID MALIGNANCIES}

\section{Burkitt's Lymphoma}

The absence of CD58 expression is a common feature of BL, which helps tumor cells escape immunological surveillance (199). The BL cells form conjugates with EBV-specific CTLs via the LFA-1/CD45 pathway, but these conjugates fail to evoke target cell lysis in the absence of the CD2-CD58 interaction, suggesting the crucial effect of CD58 in activating EBV-specific CTLs (200). To some extent, the loss of CD58 in EBV-positive BL is the basis for neoplastic cells to evade virus-specific T cell control.

\section{Hodgkin's Lymphoma}

The formation of $\mathrm{T}$ cell rosettes in $\mathrm{HL}$ relied on the IS, and activation of rosetting $\mathrm{T}$ lymphocytes is dependent on the CD2CD58 interaction (201). Although CD58 mutations in primary Reed/Sternberg (HRS) cells are rare, inactivating mutations in CD58 are common in HL cell lines and relapsed HL patients $(202,203)$. At the advanced stage of HL, CD58 inactivation of HRS cells located in pleural effusions is extremely prevalent, which provides favorable conditions for the immune escape of tumor cells (202).

\section{Diffuse Large B Cell Lymphoma}

Recently, several studies have reported that CD58 plays a key role in the pathophysiology of DLBCL. Genomic inactivation or mutation of CD58 causes loss of surface expression that is an independent adverse prognostic factor in DLBCL (204). An attenuation in T/NKmediated cell lysis in DLBCL can be restored by re-expression of wild-type CD58 (205), indicating the absence of CD58 is beneficial to disturb recognition between DLBCL cells and T/NK cells in a CD2/CD58-dependent manner to evade immunosurveillance. Besides, EZH2 inhibitor can restore CD58 expression on the surface of lymphoma cells, which in turn increases IFN- $\gamma$ secretion of T/NK cells against lymphoma cells. Mechanistically, there is a highly trimethylated H3K27 in the promoter region of CD58, which induces CD58 gene silencing and mediates immune escape of lymphoma cells, whereas EZH2 inhibitor can effectively rescue epigenetic repression of CD58 expression through boosting its demethylation and activating CD58 gene transcription (206). In addition to DLBCL, the CD58 gene is also one of the recurrent targets of genetic abnormalities in other lymphoid malignancies, such as acute adult $\mathrm{T}$ cell lymphoma and peripheral $\mathrm{T}$ cell lymphoma $(207,208)$. Taken together, these studies support the notion that the CD58 molecule plays a vital role in tumor cell biology and highlight that regulation of the adhesion molecule CD58 on the surface of tumor cells may be a promising immunotherapeutic strategy.

\section{Solid Tumors}

An increasing number of studies have revealed that the CD58 molecule plays the crucial roles in immune evasion of solid tumor cells. In neuroblastoma, CD58 is critical for the susceptibility of it to the cytotoxic effects of LAK and NK cells. Blocking CD58 on neuroblastoma cells could attenuate NK and LAK cytotoxicity (209). In colorectal cancer (CRC), Lorenz et al. (210) constructed a recombinant virus bearing CD58 (rv-CD58) to evaluate the role of CD58 on neoplastic cell immunogenicity. CRC cells infected by rv-
CD58 were potently positive for CD58 and effectively potentiated intercellular adhesion, stimulated the $\mathrm{T}$ cell proliferation, and augmented CTL cytotoxicity. In the immunocompetent C57BL/6 mice model, rv-CD58-infected murine CRC cells significantly refrained tumor growth and induced antitumor immunity (210).

In addition to mediating $\mathrm{T}$ immune response in solid tumors, several recent reports have demonstrated that CD58 molecule can serve as stem cell marker or an oncogene in tumor initiation and progression. Xu et al. (211) found that CD58 was highly expressed in CRC, CD58-positive tumor cells were frequently present in primary specimens and CRC cell lines, and demonstrated increased tumorigenicity in vitro and in vivo. More importantly, elevated CD58 facilitated the self-renewal of CRC-initiating cells through activating the $\mathrm{Wnt} / \mathrm{\beta}$-catenin pathway by degradation of Dickkopf 3. Besides, CD58 silence notably dampened sphere formation and tumor growth (211). In gastric cancer (GC), high levels of CD58 are associated with cell dedifferentiation, invasion of tumor cells into lymph and blood vessels, decreased survival time, and cancer recurrence (212). Primary tumors and metastatic lymph nodes showed extensive expression of CD58. Furthermore, distant metastases, such as peritoneum and liver, have consistently high proportions of $\mathrm{CD}^{+} 8^{+} \mathrm{GC}$ cells (212), indicating CD58 provides a selective advantage for GC cells to establish novel distant metastatic sites. Notably, upregulation of CD58 expression in tumors appears to contradict its role as a $\mathrm{T}$ cell costimulatory molecule, as high expression of CD58 on the surface of tumor cells may be more readily recognized and killed by $\mathrm{T}$ cells. Therefore, the function of CD58 in tumor cells is not simple and isolated, but complex and diverse, and needs to be further investigated in depth.

Although immune checkpoint blockade (ICB) therapy has exhibited unprecedented clinical efficacy in tumor treatment $(213,214)$, ICB still lacks efficacy in the majority of cancer patients (215). A recent study reported that the surface expression of CD58 was strongly reduced in tumor cells of melanoma patients with ICB resistance compared with that of untreated patients (216). CD58 loss induced immune evasion in different co-culture models with CTLs, and the PD-L1 expression was elevated in CD58-knockout melanoma cells (216). These data illustrated that the loss of CD58 facilitated immune evasion possibly via different mechanisms, including deficiency of $\mathrm{T}$ cell costimulation, reduction of $\mathrm{T}$ cell adhesion, and even synergy of the corepressor PD-L1. Thus, elevating CD58 expression is likely to contribute to the alleviation of ICB resistance in melanoma patients. In particular, the expression of CD58 was independent of the IFN- $\gamma$ pathway, and the loss of CD58 led to immune escape without affecting MHC expression (216), indicating that it differs from the known mechanisms of ICB resistance.

\section{CONCLUSION}

Herein, we have comprehensively summarized CD58 isoforms, sCD58, CD2-CD58 interaction, their structure and function, IS formation, CD58 polymorphisms, meanwhile discussed the crucial roles of CD58 as a costimulatory molecule for T/NK cell-mediated immune response in tumor-related and immune- 
related diseases. Regarding the roles of CD58 in tumor immunology, a looming but promising picture begins to come into sight from current studies (Table 1). On the one hand, loss of surface-related CD58 expression attenuates the susceptibility of tumor cells to CTL-mediated cytolysis; on the other hand, the local accumulation of sCD58 in the tumor microenvironment is likely to interfere with the adhesion and recognition of T/NK cells by serving as a natural immunosuppressor (Figure 4). The sCD58-mediated interference is not only for the recognition of the tumor cells themselves, but also includes $\mathrm{T}$ cell interaction with APCs. Only CD3/TCR-related signals alone without CD2CD58 costimulatory signal may result in T cell anergy. Of note, the inhibitory effect incurred by sCD58 in the microenvironment is not only due to physical blockage of cell-cell interactions, but may also involve negative signaling inside T/NK cells through sCD58-CD2 interactions. These CD58-mediated possible mechanisms facilitate immune evasion and metastasis of tumor cells, although further in-depth studies are needed. The ideal clinical application model of CD58 in cancer immunology is to stimulate the surface expression of CD58 on cancer cells and to

TABLE 1 | Expression, function and clinical significance of CD58 in various malignancies.

\begin{tabular}{|c|c|c|c|c|c|c|}
\hline $\begin{array}{l}\text { Malignancy } \\
\text { types }\end{array}$ & Expression & Functions & Mechanisms & Clinical characteristics & Prognosis & References \\
\hline $\begin{array}{l}\text { Acute } \\
\text { lymphoid } \\
\text { leukemia }\end{array}$ & Downregulated & NA & NA & $\begin{array}{l}\text { The percent of peripheral blast } \\
\text { cells, leucocytosis, and the } \\
\text { presence of a clinical tumoral } \\
\text { syndrome }\end{array}$ & $\begin{array}{l}\text { Overall } \\
\text { survival }\end{array}$ & $(190,191)$ \\
\hline $\begin{array}{l}\text { B-cell } \\
\text { progenitor ALL }\end{array}$ & Upregulated & NA & NA & $\begin{array}{l}\text { Identification marker; the } \\
\text { detection of minimum residual } \\
\text { disease }\end{array}$ & NA & $(194-196)$ \\
\hline $\begin{array}{l}\text { Acute } \\
\text { myelocytic } \\
\text { leukemia }\end{array}$ & Downregulated & Evading immunosurveillance & NA & Complete remission rate & $\begin{array}{l}\text { Overall } \\
\text { survival and } \\
\text { disease-free } \\
\text { survival }\end{array}$ & (191) \\
\hline $\begin{array}{l}\text { Chronic } \\
\text { myelocytic } \\
\text { leukemia }\end{array}$ & Downregulated & $\begin{array}{l}\text { Abnormal adhesion of } \mathrm{CML} \\
\text { progenitor cells and abnormal clonal } \\
\text { proliferation of } \mathrm{T} \text { cells }\end{array}$ & NA & NA & NA & $(197)$ \\
\hline $\begin{array}{l}\text { Burkitt's } \\
\text { Lymphoma }\end{array}$ & Downregulated & Evading immunosurveillance & NA & NA & NA & $(200)$ \\
\hline $\begin{array}{l}\text { Hodgkin's } \\
\text { lymphoma }\end{array}$ & Downregulated & Immune evasion & NA & $\begin{array}{l}\text { At the advanced stage of } \mathrm{HL} \text {, } \\
\text { CD58 inactivation of HRS cells } \\
\text { located in pleural effusions is } \\
\text { extremely prevalent }\end{array}$ & $\begin{array}{l}\text { Relapse of } \\
\text { HL }\end{array}$ & $(202,203)$ \\
\hline $\begin{array}{l}\text { Diffuse large B } \\
\text { cell lymphoma }\end{array}$ & Downregulated & Evading immunosurveillance & $\begin{array}{l}\text { Inhibiting IFN- } \gamma \text { secretion of } \\
\text { T/NK cells against lymphoma } \\
\text { cells }\end{array}$ & NA & $\begin{array}{l}\text { An } \\
\text { independent } \\
\text { adverse } \\
\text { prognostic } \\
\text { factor }\end{array}$ & $(204-206)$ \\
\hline Neuroblastoma & NA & $\begin{array}{l}\text { Susceptibility of it to the cytotoxic } \\
\text { effects of LAK and NK cells }\end{array}$ & NA & NA & NA & $(209)$ \\
\hline $\begin{array}{l}\text { Hepatocellular } \\
\text { carcinoma }\end{array}$ & $\begin{array}{l}\text { Upregulated } \\
\text { in anisomycin- } \\
\text { treated } \\
\text { HCC cells }\end{array}$ & $\begin{array}{l}\text { Promotion of immune synapse } \\
\text { formation to boost NK- } \\
\text { mediated immunotherapeutic effects }\end{array}$ & NA & NA & NA & $(76)$ \\
\hline Gastric cancer & NA & NA & NA & $\begin{array}{l}\text { Cell dedifferentiation, invasion of } \\
\text { lymph and blood vessels, } \\
\text { distant metastases }\end{array}$ & $\begin{array}{l}\text { Overall } \\
\text { survival and } \\
\text { disease-free } \\
\text { survival }\end{array}$ & $(212)$ \\
\hline \multirow[t]{2}{*}{$\begin{array}{l}\text { Colorectal } \\
\text { cancer }\end{array}$} & NA & $\begin{array}{l}\text { Potentiation of intercellular } \\
\text { adhesion, stimulation of the T cell } \\
\text { proliferation, and augment of CTL } \\
\text { cytotoxicity }\end{array}$ & NA & NA & NA & $(210)$ \\
\hline & Upregulated & $\begin{array}{l}\text { Enhancement of sphere formation, } \\
\text { EMT ability and tumor growth; } \\
\text { Promotion of self-renewal of cancer } \\
\text { stem cell }\end{array}$ & $\begin{array}{l}\text { Activating the Wnt/ } \beta \text {-catenin } \\
\text { pathway by degradation of } \\
\text { Dickkopf } 3\end{array}$ & NA & NA & $(211)$ \\
\hline Melanoma & $\begin{array}{l}\text { Downregulated } \\
\text { in patients with } \\
\text { ICB-resistance }\end{array}$ & Immune evasion & $\begin{array}{l}\text { Deficiency of T cell } \\
\text { costimulation, reduced T cell } \\
\text { adhesion, and even synergy of } \\
\text { the corepressor PD-L1. }\end{array}$ & $\begin{array}{l}\text { Increasing CD58 expression } \\
\text { contributes to alleviate ICB } \\
\text { resistance }\end{array}$ & NA & $(56,216)$ \\
\hline
\end{tabular}

NA, not available. The presence of NA in the table is due to the lack of information on related studies. ALL, acute lymphoid leukemia; CML, chronic myelocytic leukemia; HL, Hodgkin's Iymphoma; HCC, hepatocellular carcinoma; LAK, lymphokine-activated killing; CTL, cytotoxic Tlymphocyte; EMT, epithelial-mesenchymal transition; ICB, immune checkpoint blockade. 


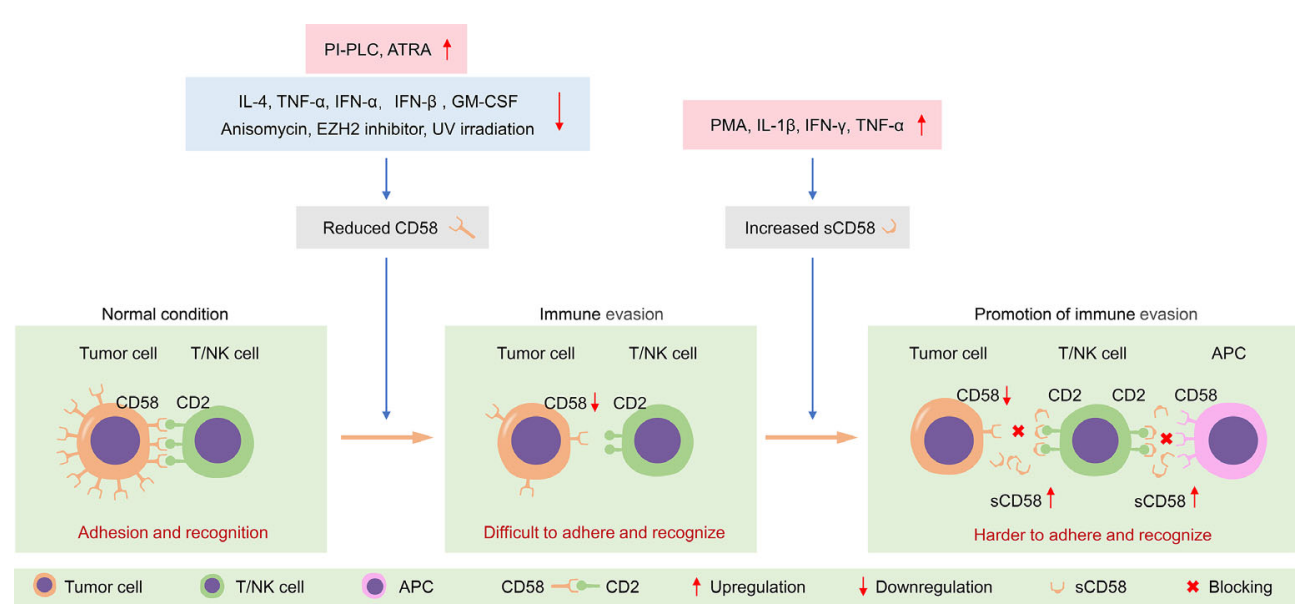

FIGURE 4 | Tumor cells evade immune surveillance by regulating the expression of CD58 on the membrane surface and sCD58 in the microenvironment. PI-PLC, phosphatidylinositol-specific phospholipase C; ATRA, all-trans retinoic acid; UV, ultraviolet; PMA, phorbol-12-myristate-13-acetate; APC, antigen-presenting cell.

inhibit the secretion of sCD58 into the tumor microenvironment, however, there still remains several pending questions (1): the molecular mechanisms of sCD58 production (2); the roles of sCD58 in varieties of cancers (3); values as a therapeutic target in autoimmune diseases and malignant tumors.

\section{AUTHOR CONTRIBUTIONS}

YZ conceived and drafted the manuscript. QFL revised the manuscript. All authors contributed to the article and approved the submitted version.

\section{REFERENCES}

1. Shaw S, Luce GE, Quinones R, Gress RE, Springer TA, Sanders ME. Two Antigen-Independent Adhesion Pathways Used by Human Cytotoxic T-cell Clones. Nature (1986) 323(6085):262-4. doi: 10.1038/323262a0

2. Moller P, Koretz K, Schlag P, Momburg F. Frequency of Abnormal Expression of HLA-A,B,C and HLA-DR Molecules, Invariant Chain, and LFA-3 (CD58) in Colorectal Carcinoma and Its Impact on Tumor Recurrence. Int J Cancer Suppl (1991) 6:155-62. doi: 10.1002/ijc.2910470727

3. Krensky AM, Sanchez-Madrid F, Robbins E, Nagy JA, Springer TA, Burakoff SJ. The Functional Significance, Distribution, and Structure of LFA-1, LFA-2, and LFA-3: Cell Surface Antigens Associated With CTLTarget Interactions. J Immunol (1983) 131(2):611-6.

4. Krensky AM, Robbins E, Springer TA, Burakoff SJ. LFA-1, LFA-2, and LFA3 Antigens Are Involved in CTL-Target Conjugation. J Immunol (1984) 132 (5):2180-2.

5. Moingeon P, Chang HC, Wallner BP, Stebbins C, Frey AZ, Reinherz EL. CD2-Mediated Adhesion Facilitates T Lymphocyte Antigen Recognition Function. Nature (1989) 339(6222):312-4. doi: 10.1038/339312a0

6. Koyasu S, Lawton T, Novick D, Recny MA, Siliciano RF, Wallner BP, et al. Role of Interaction of CD2 Molecules With Lymphocyte FunctionAssociated Antigen 3 in T-Cell Recognition of Nominal Antigen. Proc Natl Acad Sci USA (1990) 87(7):2603-7. doi: 10.1073/pnas.87.7.2603

7. Bierer BE, Burakoff SJ. T Cell Adhesion Molecules. FASEB J (1988) 2 (10):2584-90. doi: 10.1096/fasebj.2.10.2838364

8. Sanchez-Madrid F, Krensky AM, Ware CF, Robbins E, Strominger JL, Burakoff SJ, et al. Three Distinct Antigens Associated With Human T-

\section{FUNDING}

This work was supported by the National Natural Science Foundation of China (81872501, 81673023, 81272573, and $81502068)$ and the Beijing Natural Science Foundation (7172177).

\section{ACKNOWLEDGMENTS}

We thank Dr. Yunfeng Zhang and Yinuo Zhang for their encouragement and support.

Lymphocyte-Mediated Cytolysis: LFA-1, LFA-2, and LFA-3. Proc Natl Acad Sci USA (1982) 79(23):7489-93. doi: 10.1073/pnas.79.23.7489

9. Sewell WA, Palmer RW, Spurr NK, Sheer D, Brown MH, Bell Y, et al. The Human LFA-3 Gene Is Located at the Same Chromosome Band as the Gene for Its Receptor Cd2. Immunogenetics (1988) 28(4):278-82. doi: 10.1007/ BF00345506

10. Takai Y, Reed ML, Burakoff SJ, Herrmann SH. Direct Evidence for a Receptor-Ligand Interaction Between the T-Cell Surface Antigen CD2 and Lymphocyte-Function-Associated Antigen 3. Proc Natl Acad Sci USA (1987) 84(19):6864-8. doi: 10.1073/pnas.84.19.6864

11. Selvaraj P, Plunkett ML, Dustin M, Sanders ME, Shaw S, Springer TA. The T Lymphocyte Glycoprotein Cd2 Binds the Cell Surface Ligand LFA-3. Nature (1987) 326(6111):400-3. doi: 10.1038/326400a0

12. Dustin ML, Sanders ME, Shaw S, Springer TA. Purified Lymphocyte Function-Associated Antigen 3 Binds to CD2 and Mediates T Lymphocyte Adhesion. J Exp Med (1987) 165(3):677-92. doi: 10.1084/ jem.165.3.677

13. Bierer BE, Hahn WC. T Cell Adhesion, Avidity Regulation and Signaling: A Molecular Analysis of CD2. Semin Immunol (1993) 5(4):249-61. doi: 10.1006/smim.1993.1029

14. Miller GT, Hochman PS, Meier W, Tizard R, Bixler SA, Rosa MD, et al Specific Interaction of Lymphocyte Function-Associated Antigen 3 With CD2 Can Inhibit T Cell Responses. J Exp Med (1993) 178(1):211-22. doi: $10.1084 /$ jem.178.1.211

15. Itzhaky D, Raz N, Hollander N. The Glycosylphosphatidylinositol-Anchored Form and the Transmembrane Form of CD58 Associate With Protein Kinases. J Immunol (1998) 160(9):4361-6. 
16. Schirren CA, Volpel H, Meuer SC. Adhesion Molecules on Freshly Recovered T Leukemias Promote Tumor-Directed Lympholysis. Blood (1992) 79(1):138-43. doi: 10.1182/blood.V79.1.138.138

17. Seed B. An LFA-3 cDNA Encodes a Phospholipid-Linked Membrane Protein Homologous to Its Receptor Cd2. Nature (1987) 329(6142):840-2. doi: $10.1038 / 329840 \mathrm{a} 0$

18. Springer TA. Adhesion Receptors of the Immune System. Nature (1990) 346 (6283):425-34. doi: 10.1038/346425a0

19. Wallner BP, Frey AZ, Tizard R, Mattaliano RJ, Hession C, Sanders ME, et al. Primary Structure of Lymphocyte Function-Associated Antigen 3 (LFA-3). The Ligand of the T Lymphocyte CD2 Glycoprotein. J Exp Med (1987) 166 (4):923-32. doi: 10.1084/jem.166.4.923

20. Ariel O, Kukulansky T, Raz N, Hollander N. Distinct Membrane Localization and Kinase Association of the Two Isoforms of CD58. Cell Signal (2004) 16(6):667-73. doi: 10.1016/j.cellsig.2003.08.015

21. Ariel O, Levi Y, Hollander N. Signal Transduction by CD58: The Transmembrane Isoform Transmits Signals Outside Lipid Rafts Independently of the GPI-Anchored Isoform. Cell Signal (2009) 21 (7):1100-8. doi: 10.1016/j.cellsig.2009.02.022

22. Chan PY, Lawrence MB, Dustin ML, Ferguson LM, Golan DE, Springer TA. Influence of Receptor Lateral Mobility on Adhesion Strengthening Between Membranes Containing LFA-3 and CD2. J Cell Biol (1991) 115(1):245-55. doi: $10.1083 /$ jcb.115.1.245

23. Dustin ML, Selvaraj P, Mattaliano RJ, Springer TA. Anchoring Mechanisms for LFA-3 Cell Adhesion Glycoprotein at Membrane Surface. Nature (1987) 329(6142):846-8. doi: 10.1038/329846a 0

24. Tiefenthaler G, Dustin ML, Springer TA, Hunig T. Serologic CrossReactivity of T11 Target Structure and Lymphocyte Function-Associated Antigen 3. Evidence for Structural Homology of the Sheep and Human Ligands of CD2. J Immunol (1987) 139(8):2696-701.

25. Selvaraj P, Dustin ML, Mitnacht R, Hunig T, Springer TA, Plunkett ML. Rosetting of Human T Lymphocytes With Sheep and Human Erythrocytes. Comparison of Human and Sheep Ligand Binding Using Purified E Receptor. J Immunol (1987) 139(8):2690-5.

26. Patarroyo M, Makgoba MW. Leucocyte Adhesion to Cells in Immune and Inflammatory Responses. Lancet (1989) 2(8672):1139-42. doi: 10.1016/ s0140-6736(89)91498-0

27. Plunkett ML, Sanders ME, Selvaraj P, Dustin ML, Springer TA. Rosetting of Activated Human T Lymphocytes With Autologous Erythrocytes. Definition of the Receptor and Ligand Molecules as CD2 and Lymphocyte FunctionAssociated Antigen 3 (LFA-3). J Exp Med (1987) 165(3):664-76. doi: 10.1084/jem.165.3.664

28. Kearney A, Avramovic A, Castro MA, Carmo AM, Davis SJ, van der Merwe PA. The Contribution of Conformational Adjustments and Long-Range Electrostatic Forces to the CD2/CD58 Interaction. J Biol Chem (2007) 282 (18):13160-6. doi: 10.1074/jbc.M700829200

29. Hoffmann JC, Dengler TJ, Knolle PA, Albert-Wolf M, Roux M, Wallich R, et al. A Soluble Form of the Adhesion Receptor CD58 (LFA-3) Is Present in Human Body Fluids. Eur J Immunol (1993) 23(11):3003-10. doi: 10.1002/ eji.1830231142

30. Dengler TJ, Hoffmann JC, Knolle P, Albert-Wolf M, Roux M, Wallich R, et al. Structural and Functional Epitopes of the Human Adhesion Receptor CD58 (LFA-3). Eur J Immunol (1992) 22(11):2809-17. doi: 10.1002/eji.1830221109

31. Wang JH, Smolyar A, Tan K, Liu JH, Kim M, Sun ZY, et al. Structure of a Heterophilic Adhesion Complex Between the Human CD2 and CD58 (LFA-3) Counterreceptors. Cell (1999) 97(6):791-803. doi: 10.1016/s00928674(00)80790-4

32. Arulanandam AR, Withka JM, Wyss DF, Wagner G, Kister A, Pallai P, et al. The CD58 (Lfa-3) Binding Site Is a Localized and Highly Charged Surface Area on the AGFCC'c" Face of the Human Cd2 Adhesion Domain. Proc Natl Acad Sci USA (1993) 90(24):11613-7. doi: 10.1073/ pnas.90.24.11613

33. Ikemizu S, Sparks LM, van der Merwe PA, Harlos K, Stuart DI, Jones EY, et al. Crystal Structure of the CD2-Binding Domain of CD58 (Lymphocyte Function-Associated Antigen 3) at 1.8-A Resolution. Proc Natl Acad Sci USA (1999) 96(8):4289-94. doi: 10.1073/pnas.96.8.4289

34. Leherte L, Petit A, Jacquemin D, Vercauteren DP, Laurent AD. Investigating Cyclic Peptides Inhibiting Cd2-Cd58 Interactions Through Molecular
Dynamics and Molecular Docking Methods. J Comput Aided Mol Des (2018) 32(11):1295-313. doi: 10.1007/s10822-018-0172-4

35. Wang J, Reinherz EL. Structural Basis of Cell-Cell Interactions in the Immune System. Curr Opin Struct Biol (2000) 10(6):656-61. doi: 10.1016/ s0959-440x(00)00150-0

36. Davis SJ, Ikemizu S, Wild MK, van der Merwe PA. CD2 and the Nature of Protein Interactions Mediating Cell-Cell Recognition. Immunol Rev (1998) 163:217-36. doi: 10.1111/j.1600-065x.1998.tb01199.x

37. Sun ZY, Dotsch V, Kim M, Li J, Reinherz EL, Wagner G. Functional GlycanFree Adhesion Domain of Human Cell Surface Receptor CD58: Design, Production and NMR Studies. EMBO J (1999) 18(11):2941-9. doi: 10.1093/ emboj/18.11.2941

38. Yang JJ, Ye Y, Carroll A, Yang W, Lee HW. Structural Biology of the Cell Adhesion Protein CD2: Alternatively Folded States and Structure-Function Relation. Curr Protein Pept Sci (2001) 2(1):1-17. doi: 10.2174/1389203013381251

39. Dustin ML. Adhesive Bond Dynamics in Contacts Between T Lymphocytes and Glass-Supported Planar Bilayers Reconstituted With the ImmunoglobulinRelated Adhesion Molecule Cd58. J Biol Chem (1997) 272(25):15782-8. doi: $10.1074 / \mathrm{jbc} .272 .25 .15782$

40. Jones EY, Davis SJ, Williams AF, Harlos K, Stuart DI. Crystal Structure at 2.8 A Resolution of a Soluble Form of the Cell Adhesion Molecule Cd2. Nature (1992) 360(6401):232-9. doi: 10.1038/360232a0

41. He Q, Beyers AD, Barclay AN, Williams AF. A Role in Transmembrane Signaling for the Cytoplasmic Domain of the CD2 T Lymphocyte Surface Antigen. Cell (1988) 54(7):979-84. doi: 10.1016/0092-8674(88)90112-2

42. Hahn WC, Rosenstein Y, Calvo V, Burakoff SJ, Bierer BE. A Distinct Cytoplasmic Domain of CD2 Regulates Ligand Avidity and T-Cell Responsiveness to Antigen. Proc Natl Acad Sci USA (1992) 89(15):717983. doi: $10.1073 /$ pnas.89.15.7179

43. Bell GM, Fargnoli J, Bolen JB, Kish L, Imboden JB. The SH3 Domain of P56lck Binds to Proline-Rich Sequences in the Cytoplasmic Domain of CD2. J Exp Med (1996) 183(1):169-78. doi: 10.1084/jem.183.1.169

44. Thomas D, Rathinavel AK, Radhakrishnan P. Altered Glycosylation in Cancer: A Promising Target for Biomarkers and Therapeutics. Biochim Biophys Acta Rev Cancer (2020) 1875(1):188464. doi: 10.1016/j.bbcan.2020.188464

45. Wang X, Ji CG, Zhang JZ. Glycosylation Modulates Human CD2-CD58 Adhesion Via Conformational Adjustment. J Phys Chem B (2015) 119 (22):6493-501. doi: 10.1021/jp509949b

46. Albert-Wolf M, Meuer SC, Wallich R. Dual Function of Recombinant Human CD58: Inhibition of T Cell Adhesion and Activation Via the CD2 Pathway. Int Immunol (1991) 3(12):1335-47. doi: 10.1093/intimm/ 3.12.1335

47. Kim M, Sun ZY, Byron O, Campbell G, Wagner G, Wang J, et al. Molecular Dissection of the CD2-CD58 Counter-Receptor Interface Identifies CD2 Tyr86 and CD58 Lys34 Residues as the Functional "Hot Spot". J Mol Biol (2001) 312(4):711-20. doi: 10.1006/jmbi.2001.4980

48. Gokhale A, Weldeghiorghis TK, Taneja V, Satyanarayanajois SD. Conformationally Constrained Peptides From CD2 to Modulate ProteinProtein Interactions Between CD2 and CD58. J Med Chem (2011) 54 (15):5307-19. doi: 10.1021/jm200004e

49. Gokhale A, Kanthala S, Latendresse J, Taneja V, Satyanarayanajois S. Immunosuppression by Co-Stimulatory Molecules: Inhibition of CD2CD48/CD58 Interaction by Peptides From CD2 to Suppress Progression of Collagen-Induced Arthritis in Mice. Chem Biol Drug Des (2013) 82 (1):106-18. doi: 10.1111/cbdd.12138

50. Gokhale AS, Sable R, Walker JD, McLaughlin L, Kousoulas KG, Jois SD. Inhibition of Cell Adhesion and Immune Responses in the Mouse Model of Collagen-Induced Arthritis With a Peptidomimetic That Blocks CD2-CD58 Interface Interactions. Biopolymers (2015) 104(6):733-42. doi: 10.1002/bip.22692

51. Mrowietz U. Treatment Targeted to Cell Surface Epitopes. Clin Exp Dermatol (2002) 27(7):591-6. doi: 10.1046/j.1365-2230.2002.01171.x

52. Chamian F, Lin SL, Lee E, Kikuchi T, Gilleaudeau P, Sullivan-Whalen M, et al. Alefacept (Anti-CD2) Causes a Selective Reduction in Circulating Effector Memory T Cells (TEM) and Relative Preservation of Central Memory T Cells (Tcm) in Psoriasis. J Transl Med (2007) 5:27. doi: $10.1186 / 1479-5876-5-27$

53. Rigby MR, Harris KM, Pinckney A, DiMeglio LA, Rendell MS, Felner EI, et al. Alefacept Provides Sustained Clinical and Immunological Effects in 
New-Onset Type 1 Diabetes Patients. J Clin Invest (2015) 125(8):3285-96. doi: 10.1172/JCI81722

54. Vlieghe P, Lisowski V, Martinez J, Khrestchatisky M. Synthetic Therapeutic Peptides: Science and Market. Drug Discovery Today (2010) 15(1-2):40-56. doi: 10.1016/j.drudis.2009.10.009

55. Sable R, Durek T, Taneja V, Craik DJ, Pallerla S, Gauthier T, et al. Constrained Cyclic Peptides as Immunomodulatory Inhibitors of the CD2:CD58 Protein-Protein Interaction. ACS Chem Biol (2016) 11 (8):2366-74. doi: 10.1021/acschembio.6b00486

56. Scheibenbogen C, Keilholz U, Meuer S, Dengler T, Tilgen W, Hunstein W. Differential Expression and Release of LFA-3 and ICAM-1 in Human Melanoma Cell Lines. Int J Cancer (1993) 54(3):494-8. doi: 10.1002/ ijc. 2910540323

57. Hollander N, Selvaraj P, Springer TA. Biosynthesis and Function of LFA-3 in Human Mutant Cells Deficient in Phosphatidylinositol-Anchored Proteins. J Immunol (1988) 141(12):4283-90.

58. Itzhaky D, Raz N, Hollander N. The Glycosylphosphatidylinositol-Anchored Form and the Transmembrane Form of CD58 are Released From the Cell Surface Upon Antibody Binding. Cell Immunol (1998) 187(2):151-7. doi: $10.1006 /$ cimm.1998.1323

59. Bazil V. Physiological Enzymatic Cleavage of Leukocyte Membrane Molecules. Immunol Today (1995) 16(3):135-40. doi: 10.1016/0167-5699 (95) $80130-8$

60. Kirby AC, Cahen P, Porter SR, Olsen I. Soluble and Cell-Associated Forms of the Adhesion Molecule LFA-3 (CD58) Are Differentially Regulated by Inflammatory Cytokines. Cell Adhes Commun (2000) 7(6):453-64. doi: $10.3109 / 15419060009040303$

61. Une C, Gronberg A, Axberg I, Jondal M, Orn A. Phospholipase C Treatment of Certain Human Target Cells Reduces Their Susceptibility to NK Lysis Without Affecting Binding or Sensitivity to Lytic Granules. Cell Immunol (1991) 133(1):127-37. doi: 10.1016/0008-8749(91)90185-e

62. Vollger LW, Tuck DT, Springer TA, Haynes BF, Singer KH. Thymocyte Binding to Human Thymic Epithelial Cells Is Inhibited by Monoclonal Antibodies to CD-2 and LFA-3 Antigens. J Immunol (1987) 138(2):358-63.

63. Emilie D, Wallon C, Galanaud P, Fischer A, Olive D, Delfraissy JF. Role of the LFA3-CD2 Interaction in Human Specific B Cell Differentiation. J Immunol (1988) 141(6):1912-8.

64. Yamashita K, Kakutani T, Ohashi T, Saibara T. A Dimeric Form of Soluble Recombinant Sheep LFA-3(CD58) Inhibits Human T-Cell Proliferation by Generating Regulatory T Cells. Immunopharmacology (1997) 37(2-3):20920. doi: 10.1016/s0162-3109(97)00050-7

65. Yamashita K, Parish CR, Warren HS, Harrison LC. A Multimeric Form of Soluble Recombinant Sheep LFA-3 (CD58) Inhibits Human T-Cell Proliferation. Immunology (1997) 92(1):39-44. doi: 10.1046/j.13652567.1997.00317x

66. Hutchins D, Steel CM. Regulation of ICAM-1 (Cd54) Expression in Human Breast Cancer Cell Lines by Interleukin 6 and Fibroblast-Derived Factors. Int J Cancer (1994) 58(1):80-4. doi: 10.1002/ijc.2910580114

67. Kvale D, Krajci P, Brandtzaeg P. Expression and Regulation of Adhesion Molecules ICAM-1 (CD54) and LFA-3 (CD58) in Human Intestinal Epithelial Cell Lines. Scand J Immunol (1992) 35(6):669-76. doi: 10.1111/ j.1365-3083.1992.tb02973.x

68. Kvale D, Brandtzaeg P. Immune Modulation of Adhesion Molecules ICAM1 (CD54) and LFA-3 (CD58) in Human Hepatocytic Cell Lines. J Hepatol (1993) 17(3):347-52. doi: 10.1016/s0168-8278(05)80216-8

69. Bloemen PG, van den Tweel MC, Henricks PA, Engels F, Wagenaar SS, Rutten AA, et al. Expression and Modulation of Adhesion Molecules on Human Bronchial Epithelial Cells. Am J Respir Cell Mol Biol (1993) 9 (6):586-93. doi: $10.1165 / \mathrm{ajrcmb} / 9.6 .586$

70. Weber F, Meinl E, Aloisi F, Nevinny-Stickel C, Albert E, Wekerle H, et al. Human Astrocytes are Only Partially Competent Antigen Presenting Cells. Possible Implications for Lesion Development in Multiple Sclerosis. Brain (1994) 117( Pt 1):59-69. doi: 10.1093/brain/117.1.59

71. Shubinsky G, Schlesinger M. Kinetics of the Pleiotropic Effect of Interleukin 4 on the Surface Properties of Human B-Lymphoma Cells. Leuk Lymphoma (1994) 15(3-4):333-40. doi: 10.3109/10428199409049732

72. Rousset F, Billaud M, Blanchard D, Figdor C, Lenoir GM, Spits H, et al. Il-4 Induces LFA-1 and LFA-3 Expression on Burkitt's Lymphoma Cell Lines.
Requirement of Additional Activation by Phorbol Myristate Acetate for Induction of Homotypic Cell Adhesions. J Immunol (1989) 143(5):1490-8.

73. Schirren CA, Volpel H, Hoffmann JC, Henning SW, Qiao L, Autschbach F, et al. Biological Response Modifiers Render Tumor Cells Susceptible to Autologous Effector Mechanisms by Influencing Adhesion Receptors. Leuk Lymphoma (1993) 10(1-2):25-33. doi: 10.3109/10428199309147353

74. Bendall LJ, Kortlepel K, Gottlieb DJ. Gm-CSF Enhances IL-2-Activated Natural Killer Cell Lysis of Clonogenic Aml Cells by Upregulating Target Cell Expression of ICAM-1. Leukemia (1995) 9(4):677-84.

75. Kobata T, Ikeda H, Ohnishi Y, Urushibara N, Nakata SO, Takahashi TA, et al. Ultraviolet Irradiation Inhibits Killer-Target Cell Interaction. Vox Sang (1993) 65(1):25-31. doi: 10.1111/j.1423-0410.1993.tb04520.x

76. Kim M, Lee SJ, Shin S, Park KS, Park SY, Lee CH. Novel Natural Killer CellMediated Cancer Immunotherapeutic Activity of Anisomycin Against Hepatocellular Carcinoma Cells. Sci Rep (2018) 8(1):10668. doi: 10.1038/ s41598-018-29048-8

77. Nakayama J, Terao H, Koga T, Furue M. Induction of CD54 and CD58 Expression in Cultured Human Endothelial Cells by Beta-Interferon With or Without Hyperthermia In Vitro. J Dermatol Sci (2001) 26(1):19-24. doi: 10.1016/s0923-1811(00)00150-x

78. Cahen P, Kirby AC, Porter SR, Olsen I. Regulation of LFA-3 (CD58) by Dexamethasone and Retinoic Acids In Vitro. Inflammation Res (2000) 49 (7):338-44. doi: 10.1007/PL00000214

79. Di Noto R, Lo Pardo C, Schiavone EM, Ferrara F, Manzo C, Vacca C, et al. All-Trans Retinoic Acid (ATRA) and the Regulation of Adhesion Molecules in Acute Myeloid Leukemia. Leuk Lymphoma (1996) 21(3-4):201-9. doi: 10.3109/10428199209067601

80. Huo X, Dai Y, Yang T, Zhang Y, Li M, Xu X. Decreased Erythrocyte CD44 and CD58 Expression Link E-Waste Pb Toxicity to Changes in Erythrocyte Immunity in Preschool Children. Sci Total Environ (2019) 664:690-7. doi: 10.1016/j.scitotenv.2019.02.040

81. van der Merwe PA, McNamee PN, Davies EA, Barclay AN, Davis SJ. Topology of the CD2-CD48 Cell-Adhesion Molecule Complex: Implications for Antigen Recognition by T Cells. Curr Biol (1995) 5 (1):74-84. doi: 10.1016/s0960-9822(95)00019-4

82. Menu E, Tsai BC, Bothwell AL, Sims PJ, Bierer BE. Cd59 Costimulation of T Cell Activation. CD58 Dependence and Requirement for Glycosylation. J Immunol (1994) 153(6):2444-56.

83. van der Merwe PA, McPherson DC, Brown MH, Barclay AN, Cyster JG, Williams AF, et al. The NH2-Terminal Domain of Rat CD2 Binds Rat CD48 With a Low Affinity and Binding Does Not Require Glycosylation of CD2. Eur J Immunol (1993) 23(6):1373-7. doi: 10.1002/eji.1830230628

84. Hahn WC, Menu E, Bothwell AL, Sims PJ, Bierer BE. Overlapping But Nonidentical Binding Sites on CD2 for CD58 and a Second Ligand CD59. Science (1992) 256(5065):1805-7. doi: 10.1126/science.1377404

85. Deckert M, Kubar J, Zoccola D, Bernard-Pomier G, Angelisova P, Horejsi V, et al. CD59 Molecule: A Second Ligand for CD2 in T Cell Adhesion. Eur J Immunol (1992) 22(11):2943-7. doi: 10.1002/eji.1830221128

86. Deckert M, Kubar J, Bernard A. CD58 and CD59 Molecules Exhibit Potentializing Effects in T Cell Adhesion and Activation. J Immunol (1992) 148(3):672-7.

87. Barbosa JA, Mentzer SJ, Kamarck ME, Hart J, Biro PA, Strominger JL, et al Gene Mapping and Somatic Cell Hybrid Analysis of the Role of Human Lymphocyte Function-Associated Antigen-3 (LFA-3) in CTL-target Cell Interactions. J Immunol (1986) 136(8):3085-91.

88. Kato K, Koyanagi M, Okada H, Takanashi T, Wong YW, Williams AF, et al. CD48 Is a Counter-Receptor for Mouse CD2 and Is Involved in T Cell Activation. J Exp Med (1992) 176(5):1241-9. doi: 10.1084/jem.176.5.1241

89. Wong YW, Williams AF, Kingsmore SF, Seldin MF. Structure, Expression, and Genetic Linkage of the Mouse BCM1 (OX45 or Blast-1) Antigen. Evidence for Genetic Duplication Giving Rise to the BCM1 Region on Mouse Chromosome 1 and the CD2/LFA3 Region on Mouse Chromosome 3. J Exp Med (1990) 171(6):2115-30. doi: 10.1084/jem.171.6.2115

90. Arulanandam AR, Moingeon P, Concino MF, Recny MA, Kato K, Yagita H, et al. A Soluble Multimeric Recombinant CD2 Protein Identifies CD48 as a Low Affinity Ligand for Human Cd2: Divergence of CD2 Ligands During the Evolution of Humans and Mice. J Exp Med (1993) 177(5):1439-50. doi: 10.1084/jem.177.5.1439 
91. Brossay A, Hube F, Moreau T, Bardos P, Watier H. Porcine CD58: Cdna Cloning and Molecular Dissection of the Porcine CD58-Human CD2 Interface. Biochem Biophys Res Commun (2003) 309(4):992-8. doi: 10.1016/j.bbrc.2003.08.099

92. Warren HS, Altin JG, Waldron JC, Kinnear BF, Parish CR. A Carbohydrate Structure Associated With CD15 (Lewis X) on Myeloid Cells Is a Novel Ligand for Human Cd2. J Immunol (1996) 156(8):2866-73.

93. Brown MH, Preston S, Barclay AN. A Sensitive Assay for Detecting LowAffinity Interactions at the Cell Surface Reveals No Additional Ligands for the Adhesion Pair Rat CD2 and CD48. Eur J Immunol (1995) 25(12):3222-8. doi: 10.1002/eji.1830251204

94. Sandrin MS, Mouhtouris E, Vaughan HA, Warren HS, Parish CR. CD48 is a Low Affinity Ligand for Human CD2. J Immunol (1993) 151(9):4606-13.

95. Chavin KD, Qin L, Lin J, Woodward J, Baliga P, Kato K, et al. Anti-CD48 (Murine CD2 Ligand) Mabs Suppress Cell Mediated Immunity In Vivo. Int Immunol (1994) 6(5):701-9. doi: 10.1093/intimm/6.5.701

96. Sido B, Otto G, Zimmermann R, Muller P, Meuer SC, Dengler TJ. Modulation of the CD2 Receptor and Not Disruption of the CD2/CD48 Interaction is the Principal Action of CD2-mediated Immunosuppression in the Rat. Cell Immunol (1997) 182(1):57-67. doi: 10.1006/cimm.1997.1204

97. Dustin ML. The Immunological Synapse. Cancer Immunol Res (2014) 2 (11):1023-33. doi: 10.1158/2326-6066.CIR-14-0161

98. Freiberg BA, Kupfer H, Maslanik W, Delli J, Kappler J, Zaller DM, et al. Staging and Resetting T Cell Activation in Smacs. Nat Immunol (2002) 3 (10):911-7. doi: 10.1038/ni836

99. Espagnolle N, Depoil D, Zaru R, Demeur C, Champagne E, Guiraud M, et al. CD2 and TCR Synergize for the Activation of Phospholipase Cgamma1/ Calcium Pathway at the Immunological Synapse. Int Immunol (2007) 19 (3):239-48. doi: 10.1093/intimm/dxl141

100. Binder C, Cvetkovski F, Sellberg F, Berg S, Paternina Visbal H, Sachs DH, et al. Cd2 Immunobiology. Front Immunol (2020) 11:1090. doi: 10.3389/ fimmu.2020.01090

101. Demetriou P, Abu-Shah E, Valvo S, McCuaig S, Mayya V, Kvalvaag A, et al. A Dynamic CD2-Rich Compartment at the Outer Edge of the Immunological Synapse Boosts and Integrates Signals. Nat Immunol (2020) 21(10):1232-43. doi: 10.1038/s41590-020-0770-x

102. Li R, Ma C, Cai H, Chen W. The CAR T-Cell Mechanoimmunology at a Glance. Adv Sci (Weinh) (2020) 7(24):2002628. doi: 10.1002/advs.202002628

103. Zhu DM, Dustin ML, Cairo CW, Thatte HS, Golan DE. Mechanisms of Cellular Avidity Regulation in CD2-CD58-Mediated T Cell Adhesion. ACS Chem Biol (2006) 1(10):649-58. doi: 10.1021/cb6002515

104. van Kemenade FJ, Tellegen E, Maurice MM, Lankester AC, Kuijpers TW, Brouwer M, et al. Simultaneous Regulation of CD2 Adhesion and Signaling Functions by a Novel CD2 Monoclonal Antibody. J Immunol (1994) 152 (9):4425-32.

105. Boussiotis VA, Freeman GJ, Griffin JD, Gray GS, Gribben JG, Nadler LM. CD2 Is Involved in Maintenance and Reversal of Human AlloantigenSpecific Clonal Anergy. J Exp Med (1994) 180(5):1665-73. doi: 10.1084/ jem.180.5.1665

106. Jenkins MK, Johnson JG. Molecules Involved in T-Cell Costimulation. Curr Opin Immunol (1993) 5(3):361-7. doi: 10.1016/0952-7915(93)90054-v

107. Janeway CA Jr., Golstein P. Lymphocyte Activation and Effector Functions. Editorial Overview. The Role of Cell Surface Molecules. Curr Opin Immunol (1993) 5(3):313-23. doi: 10.1016/0952-7915(93)90048-w

108. Samelson LE. Lymphocyte Activation. Curr Opin Immunol (1989) 2(2):2104. doi: 10.1016/0952-7915(89)90190-8

109. Turcovski-Corrales SM, Fenton RG, Peltz G, Taub DD. Cd28:B7 Interactions Promote T Cell Adhesion. Eur J Immunol (1995) 25(11):3087-93. doi: 10.1002/eji.1830251115

110. Tiefenthaler G, Hunig T, Dustin ML, Springer TA, Meuer SC. Purified Lymphocyte Function-Associated Antigen-3 and T11 Target Structure Are Active in CD2-Mediated T Cell Stimulation. Eur J Immunol (1987) 17 (12):1847-50. doi: 10.1002/eji.1830171227

111. Bierer BE, Peterson A, Barbosa J, Seed B, Burakoff SJ. Expression of the T-Cell Surface Molecule CD2 and An Epitope-Loss CD2 Mutant to Define the Role of Lymphocyte Function-Associated Antigen 3 (LFA-3) in T-Cell Activation. Proc Natl Acad Sci USA (1988) 85(4):1194-8. doi: 10.1073/pnas.85.4.1194

112. Dustin ML, Olive D, Springer TA. Correlation of CD2 Binding and Functional Properties of Multimeric and Monomeric Lymphocyte
Function-Associated Antigen 3. J Exp Med (1989) 169(2):503-17. doi: $10.1084 / \mathrm{jem} .169 .2 .503$

113. Moingeon PE, Lucich JL, Stebbins CC, Recny MA, Wallner BP, Koyasu S, et al. Complementary Roles for CD2 and LFA-1 Adhesion Pathways During T Cell Activation. Eur J Immunol (1991) 21(3):605-10. doi: 10.1002/ eji.1830210311

114. Hahn WC, Rosenstein Y, Burakoff SJ, Bierer BE. Interaction of CD2 With Its Ligand Lymphocyte Function-Associated Antigen-3 Induces Adenosine 3',5'-Cyclic Monophosphate Production in T Lymphocytes. J Immunol (1991) 147(1):14-21.

115. Kaizuka Y, Douglass AD, Vardhana S, Dustin ML, Vale RD. The Coreceptor $\mathrm{Cd} 2$ Uses Plasma Membrane Microdomains to Transduce Signals in T Cells. J Cell Biol (2009) 185(3):521-34. doi: 10.1083/jcb.200809136

116. Anton Van Der Merwe P, Davis SJ, Shaw AS, Dustin ML. Cytoskeletal Polarization and Redistribution of Cell-Surface Molecules During T Cell Antigen Recognition. Semin Immunol (2000) 12(1):5-21. doi: 10.1006/ smim.2000.0203

117. Wacholtz MC, Lipsky PE. Anti-Cd3-Stimulated Ca2+ Signal in Individual Human Peripheral T Cells. Activation Correlates With a Sustained Increase in Intracellular Ca2+1. J Immunol (1993) 150(12):5338-49.

118. Weiss A, Littman DR. Signal Transduction by Lymphocyte Antigen Receptors. Cell (1994) 76(2):263-74. doi: 10.1016/0092-8674(94)90334-4

119. Parra E, Wingren AG, Hedlund G, Kalland T, Dohlsten M. The Role of B7-1 and LFA-3 in Costimulation of CD8+ T Cells. J Immunol (1997) 158(2):63742. doi: 10.1016/S0165-2478(97)85190-5

120. Durand DB, Shaw JP, Bush MR, Replogle RE, Belagaje R, Crabtree GR. Characterization of Antigen Receptor Response Elements Within the Interleukin-2 Enhancer. Mol Cell Biol (1988) 8(4):1715-24. doi: 10.1128/ mcb.8.4.1715

121. Halvorsen R, Leivestad T, Gaudernack G, Thorsby E. Accessory CellDependent T-Cell Activation Via Ti-CD3. Involvement of CD2-LFA-3 Interactions. Scand J Immunol (1988) 28(3):277-84. doi: 10.1111/j.13653083.1988.tb01449.x

122. Parra E, Varga M, Hedlund G, Kalland T, Dohlsten M. Costimulation by B71 and LFA-3 Targets Distinct Nuclear Factors That Bind to the Interleukin-2 Promoter: B7-1 Negatively Regulates LFA-3-Induced Nf-at DNA Binding. Mol Cell Biol (1997) 17(3):1314-23. doi: 10.1128/mcb.17.3.1314

123. Parra E, Wingren AG, Hedlund G, Bjorklund M, Sjogren HO, Kalland T, et al. Costimulation of Human Cd4+ T Lymphocytes With B7 and Lymphocyte Function-Associated Antigen-3 Results in Distinct Cell Activation Profiles. J Immunol (1994) 153(6):2479-87.

124. Endler-Jobst B, Schraven B, Hutmacher B, Meuer SC. Human T Cell Responses to IL-1 and IL-6 Are Dependent on Signals Mediated Through CD2. J Immunol (1991) 146(6):1736-42.

125. Bullens DM, Rafiq K, Charitidou L, Peng X, Kasran A, Warmerdam PA, et al. Effects of Co-Stimulation by CD58 on Human T Cell Cytokine Production: A Selective Cytokine Pattern With Induction of High Il-10 Production. Int Immunol (2001) 13(2):181-91. doi: 10.1093/intimm/13.2.181

126. Cottrez F, Hurst SD, Coffman RL, Groux H. T Regulatory Cells 1 Inhibit a Th2-Specific Response In Vivo. J Immunol (2000) 165(9):4848-53. doi: 10.4049/jimmunol.165.9.4848

127. Wakkach A, Cottrez F, Groux H. Differentiation of Regulatory T Cells 1 Is Induced by CD2 Costimulation. J Immunol (2001) 167(6):3107-13. doi: 10.4049/jimmunol.167.6.3107

128. Nguyen KG, Vrabel MR, Mantooth SM, Hopkins JJ, Wagner ES, Gabaldon TA, et al. Localized Interleukin-12 for Cancer Immunotherapy. Front Immunol (2020) 11:575597. doi: 10.3389/fimmu.2020.575597

129. Gollob JA, Li J, Kawasaki H, Daley JF, Groves C, Reinherz EL, et al. Molecular Interaction Between CD58 and CD2 Counter-Receptors Mediates the Ability of Monocytes to Augment T Cell Activation by IL-12. J Immunol (1996) 157(5):1886-93.

130. Gollob JA, Li J, Reinherz EL, Ritz J. Cd2 Regulates Responsiveness of Activated T Cells to Interleukin 12. J Exp Med (1995) 182(3):721-31. doi: $10.1084 /$ jem.182.3.721

131. Gollob JA, Ritz J. Cd2-CD58 Interaction and the Control of T-Cell Interleukin-12 Responsiveness. Adhesion Molecules Link Innate and Acquired Immunity. Ann NY Acad Sci (1996) 795:71-81. doi: 10.1111/ j.1749-6632.1996.tb52656.x 
132. Dhein J, Walczak H, Baumler C, Debatin KM, Krammer PH. Autocrine TCell Suicide Mediated by APO-1/(Fas/CD95). Nature (1995) 373(6513):43841. doi: $10.1038 / 373438 \mathrm{a} 0$

133. Daniel PT, Scholz C, Essmann F, Westermann J, Pezzutto A, Dorken B. Cd95/Fas-Triggered Apoptosis of Activated T Lymphocytes Is Prevented by Dendritic Cells Through a CD58-Dependent Mechanism. Exp Hematol (1999) 27(9):1402-8. doi: 10.1016/s0301-472x(99)00079-x

134. Ayroldi E, Migliorati G, Cannarile L, Moraca R, Delfino DV, Riccardi C. CD2 Rescues T Cells From T-Cell Receptor/CD3 Apoptosis: A Role for the Fas/ Fas-L System. Blood (1997) 89(10):3717-26. doi: 10.1182/blood.V89.10.3717. 3717_3717_3726

135. Mahajan S, Gollob JA, Ritz J, Frank DA. CD2 Stimulation Leads to the Delayed and Prolonged Activation of STAT1 in T Cells But Not NK Cells. Exp Hematol (2001) 29(2):209-20. doi: 10.1016/s0301-472x(00)00652-4

136. Ortaldo JR, Winkler-Pickett RT, Yagita H, Young HA. Comparative Studies of CD3- and CD3+ Cd56+ Cells: Examination of Morphology, Functions, T Cell Receptor Rearrangement, and Pore-Forming Protein Expression. Cell Immunol (1991) 136(2):486-95. doi: 10.1016/0008-8749(91)90369-m

137. Lu PH, Negrin RS. A Novel Population of Expanded Human CD3+CD56+ Cells Derived From T Cells With Potent In Vivo Antitumor Activity in Mice With Severe Combined Immunodeficiency. J Immunol (1994) 153(4):1687-96.

138. Lopez RD, Waller EK, Lu PH, Negrin RS. CD58/LFA-3 and IL-12 Provided by Activated Monocytes Are Critical in the In Vivo Expansion of CD56+ T Cells. Cancer Immunol Immunother (2001) 49(12):629-40. doi: 10.1007/ s002620000148

139. Pangrazzi L, Weinberger B. T Cells, Aging and Senescence. Exp Gerontol (2020) 134:110887. doi: 10.1016/j.exger.2020.110887

140. Leitner J, Herndler-Brandstetter D, Zlabinger GJ, Grubeck-Loebenstein B, Steinberger P. CD58/CD2 Is the Primary Costimulatory Pathway in Human Cd28-Cd8+ T Cells. J Immunol (2015) 195(2):477-87. doi: 10.4049/ jimmunol.1401917

141. Shao T, Shi W, Zheng JY, Xu XX, Lin AF, Xiang LX, et al. Costimulatory Function of CD58/CD2 Interaction in Adaptive Humoral Immunity in a Zebrafish Model. Front Immunol (2018) 9:1204. doi: 10.3389/fimmu.2018.01204

142. Bierer BE, Barbosa J, Herrmann S, Burakoff SJ. Interaction of CD2 With Its Ligand, LFA-3, in Human T Cell Proliferation. J Immunol (1988) 140 (10):3358-63.

143. Bodey B. Development of Lymphopoiesis as a Function of the Thymic Microenvironment. Use of CD8+ Cytotoxic T Lymphocytes for Cellular Immunotherapy of Human Cancer. In Vivo (1994) 8(5):915-43.

144. Denning SM, Tuck DT, Vollger LW, Springer TA, Singer KH, Haynes BF. Monoclonal Antibodies to CD2 and Lymphocyte Function-Associated Antigen 3 Inhibit Human Thymic Epithelial Cell-Dependent Mature Thymocyte Activation. J Immunol (1987) 139(8):2573-8.

145. Cooley S, Burns LJ, Repka T, Miller JS. Natural Killer Cell Cytotoxicity of Breast Cancer Targets is Enhanced by Two Distinct Mechanisms of Antibody-Dependent Cellular Cytotoxicity Against LFA-3 and HER2/Neu. Exp Hematol (1999) 27(10):1533-41. doi: 10.1016/s0301-472x(99)00089-2

146. Comerci CJ, Mace EM, Banerjee PP, Orange JS. Cd2 Promotes Human Natural Killer Cell Membrane Nanotube Formation. PloS One (2012) 7(10): e47664. doi: 10.1371/journal.pone.0047664

147. Davis DM, Sowinski S. Membrane Nanotubes: Dynamic Long-Distance Connections Between Animal Cells. Nat Rev Mol Cell Biol (2008) 9 (6):431-6. doi: 10.1038/nrm2399

148. Robertson MJ, Caligiuri MA, Manley TJ, Levine H, Ritz J. Human Natural Killer Cell Adhesion Molecules. Differential Expression After Activation and Participation in Cytolysis. J Immunol (1990) 145(10):3194-201.

149. Maenpaa A, Jaaskelainen J, Carpen O, Patarroyo M, Timonen T. Expression of Integrins and Other Adhesion Molecules on NK Cells; Impact of IL-2 on Short- and Long-Term Cultures. Int J Cancer (1993) 53(5):850-5. doi: $10.1002 /$ ijc. 2910530524

150. Sanders ME, Makgoba MW, Sharrow SO, Stephany D, Springer TA, Young HA, et al. Human Memory T Lymphocytes Express Increased Levels of Three Cell Adhesion Molecules (LFA-3, CD2, and LFA-1) and Three Other Molecules (Uchl1, CDw29, and Pgp-1) and Have Enhanced IFN-Gamma Production. J Immunol (1988) 140(5):1401-7.

151. Crawford K, Stark A, Kitchens B, Sternheim K, Pantazopoulos V, Triantafellow E, et al. CD2 Engagement Induces Dendritic Cell Activation:
Implications for Immune Surveillance and T-Cell Activation. Blood (2003) 102(5):1745-52. doi: 10.1182/blood-2002-07-2206

152. Hoffmann JC, Kruger H, Zielen S, Bayer B, Zeidler H. Human B Cell Differentiation: Dependence on Interactions With Monocytes and $\mathrm{T}$ Lymphocytes Via CD40, CD80 (B7.1), and the CD2-Ligands CD48 and CD58 (LFA-3). Cell Biol Int (1998) 22(1):21-9. doi: 10.1006/cbir.1997.0208

153. Virella G, Rugeles MT, Hyman B, La Via M, Goust JM, Frankis M, et al. The Interaction of CD2 With its LFA-3 Ligand Expressed by Autologous Erythrocytes Results in Enhancement of B Cell Responses. Cell Immunol (1988) 116(2):308-19. doi: 10.1016/0008-8749(88)90233-x

154. Diaz-Sanchez D, Chegini S, Zhang K, Saxon A. Cd58 (LFA-3) Stimulation Provides a Signal for Human Isotype Switching and IgE Production Distinct From CD40. J Immunol (1994) 153(1):10-20.

155. Mestas J, Hughes CC. Endothelial Cell Costimulation of T Cell Activation Through CD58-CD2 Interactions Involves Lipid Raft Aggregation. J Immunol (2001) 167(8):4378-85. doi: 10.4049/jimmunol.167.8.4378

156. Karmann K, Hughes CC, Fanslow WC, Pober JS. Endothelial Cells Augment the Expression of CD40 Ligand on Newly Activated Human Cd4+ T Cells Through a CD2/LFA-3 Signaling Pathway. Eur J Immunol (1996) 26(3):6107. doi: $10.1002 /$ eji. 1830260316

157. Murakami K, Ma W, Fuleihan R, Pober JS. Human Endothelial Cells Augment Early CD40 Ligand Expression in Activated Cd4+ T Cells Through LFA-3-Mediated Stabilization of mRNA. J Immunol (1999) 163(5):2667-73.

158. van Kooyk Y, van de Wiel-van Kemenade P, Weder P, Kuijpers TW, Figdor CG. Enhancement of LFA-1-Mediated Cell Adhesion by Triggering Through CD2 or CD3 on T Lymphocytes. Nature (1989) 342(6251):811-3. doi: $10.1038 / 342811 \mathrm{a} 0$

159. Collins T, Krensky AM, Clayberger C, Fiers W, Gimbrone MA Jr., Burakoff SJ, et al. Human Cytolytic T Lymphocyte Interactions With Vascular Endothelium and Fibroblasts: Role of Effector and Target Cell Molecules. J Immunol (1984) 133(4):1878-84.

160. Ma W, Pober JS. Human Endothelial Cells Effectively Costimulate Cytokine Production by, But Not Differentiation of, Naive Cd4+ T Cells. J Immunol (1998) 161(5):2158-67.

161. Hughes CC, Pober JS. Transcriptional Regulation of the Interleukin-2 Gene in Normal Human Peripheral Blood T Cells. Convergence of Costimulatory Signals and Differences From Transformed T Cells. J Biol Chem (1996) 271 (10):5369-77. doi: 10.1074/jbc.271.10.5369

162. Damle NK, Doyle LV. Stimulation of Cloned Human T Lymphocytes Via the CD3 or CD28 Molecules Induces Enhancement in Vascular Endothelial Permeability to Macromolecules With Participation of Type- 1 and Type-2 Intercellular Adhesion Pathways. Eur J Immunol (1990) 20(9):1995-2003. doi: 10.1002/eji.1830200918

163. Framson PE, Cho DH, Lee LY, Hershberg RM. Polarized Expression and Function of the Costimulatory Molecule CD58 on Human Intestinal Epithelial Cells. Gastroenterology (1999) 116(5):1054-62. doi: 10.1016/ s0016-5085(99)70008-9

164. Ebert EC, Panja A, Praveen R. Human Intestinal Intraepithelial Lymphocytes and Epithelial Cells Coinduce Interleukin-8 Production Through the CD2CD58 Interaction. Am J Physiol Gastrointest Liver Physiol (2009) 296(3): G671-7. doi: 10.1152/ajpgi.90497.2008

165. Kim JY, Bae JS, Kim HJ, Shin HD. Cd58 Polymorphisms Associated With the Risk of Neuromyelitis Optica in a Korean Population. BMC Neurol (2014) 14:57. doi: 10.1186/1471-2377-14-57

166. Yamamoto M, Watanabe M, Inoue N, Watanabe A, Ozaki H, Ohsaki M, et al. Association of CD58 Polymorphisms and Its Protein Expression With the Development and Prognosis of Autoimmune Thyroid Diseases. Immunol Invest (2020) 49(1-2):106-19. doi: 10.1080/08820139.2019.1659811

167. Kumar V, Cheng SC, Johnson MD, Smeekens SP, Wojtowicz A, GiamarellosBourboulis E, et al. Immunochip SNP Array Identifies Novel Genetic Variants Conferring Susceptibility to Candidaemia. Nat Commun (2014) 5:4675. doi: 10.1038/ncomms5675

168. Hoppenbrouwers IA, Aulchenko YS, Janssens AC, Ramagopalan SV, Broer L, Kayser M, et al. Replication of CD58 and CLEC16A as Genome-Wide Significant Risk Genes for Multiple Sclerosis. J Hum Genet (2009) 54 (11):676-80. doi: 10.1038/jhg.2009.96

169. Coustet B, Agarwal SK, Gourh P, Guedj M, Mayes MD, Dieude P, et al. Association Study of ITGAM, ITGAX, and CD58 Autoimmune Risk Loci 
in Systemic Sclerosis: Results From 2 Large European Caucasian Cohorts. J Rheumatol (2011) 38(6):1033-8. doi: 10.3899/jrheum.101053

170. De Jager PL, Baecher-Allan C, Maier LM, Arthur AT, Ottoboni L, Barcellos L, et al. The Role of the CD58 Locus in Multiple Sclerosis. Proc Natl Acad Sci USA (2009) 106(13):5264-9. doi: 10.1073/pnas.0813310106

171. Torbati S, Karami F, Ghaffarpour M, Zamani M. Association of CD58 Polymorphism With Multiple Sclerosis and Response to Interferon Ss Therapy in A Subset of Iranian Population. Cell J (2015) 16(4):506-13. doi: 10.22074/cellj.2015.505

172. Bashinskaya VV, Kulakova OG, Kiselev IS, Baulina NM, Favorov AV, Boyko AN, et al. Gwas-Identified Multiple Sclerosis Risk Loci Involved in Immune Response: Validation in Russians. J Neuroimmunol (2015) 282:85-91. doi: 10.1016/j.jneuroim.2015.03.015

173. Hecker M, Boxberger N, Illner N, Fitzner B, Schroder I, Winkelmann A, et al. A Genetic Variant Associated With Multiple Sclerosis Inversely Affects the Expression of CD58 and Microrna-548ac From the Same Gene. PloS Genet (2019) 15(2):e1007961. doi: 10.1371/journal.pgen.1007961

174. Brynedal B, Bomfim IL, Olsson T, Duvefelt K, Hillert J. Differential Expression, and Genetic Association, of CD58 in Swedish Multiple Sclerosis Patients. Proc Natl Acad Sci USA (2009) 106(23):E58. doi: 10.1073/pnas.0904338106

175. Mitkin NA, Muratova AM, Korneev KV, Pavshintsev VV, Rumyantsev KA, Vagida MS, et al. Protective C Allele of the Single-Nucleotide Polymorphism rs1335532 Is Associated With Strong Binding of Ascl2 Transcription Factor and Elevated CD58 Expression in B-Cells. Biochim Biophys Acta Mol Basis Dis (2018) 1864(10):3211-20. doi: 10.1016/j.bbadis.2018.07.008

176. Payer LM, Steranka JP, Ardeljan D, Walker J, Fitzgerald KC, Calabresi PA, et al. Alu Insertion Variants Alter mRNA Splicing. Nucleic Acids Res (2019) 47(1):421-31. doi: 10.1093/nar/gky1086

177. Autschbach F, Meuer SC, Moebius U, Manns M, Hess G, Meyer zum Buschenfelde $\mathrm{KH}$, et al. Hepatocellular Expression of Lymphocyte Function-Associated Antigen 3 in Chronic Hepatitis. Hepatology (1991) 14 (2):223-30. doi: 10.1002/hep.1840140204

178. Xie M, Wang XL, Ji YQ, Li J, Meng ZJ, Shi L, et al. Study on the Relationship Between Level of CD58 Expression in Peripheral Blood Mononuclear Cell and Severity of HBV Infection. Chin (Engl) (2005) 118(24):2072-6.

179. Sheng L, Li J, Qi BT, Ji YQ, Meng ZJ, Xie M. Investigation on Correlation Between Expression of CD58 Molecule and Severity of Hepatitis B. World J Gastroenterol (2006) 12(26):4237-40. doi: 10.3748/wjg.v12.i26.4237

180. Hoffmann JC, Rauker HJ, Kruger H, Bayer B, Zeidler H. Decreased Levels of a Soluble Form of the Human Adhesion Receptor Cd58 (Lfa-3) in Sera and Synovial Fluids of Patients With Rheumatoid Arthritis. Clin Exp Rheumatol (1996) 14(1):23-9.

181. Hoffmann JC, Bayer B, Zeidler H. Characterization of a Soluble Form of CD58 in Synovial Fluid of Patients With Rheumatoid Arthritis (Ra). Clin Exp Immunol (1996) 104(3):460-6. doi: 10.1046/j.1365-2249.1996.41749.x

182. Craigen JL, Grundy JE. Cytomegalovirus Induced Up-Regulation of LFA-3 (CD58) and ICAM-1 (CD54) is a Direct Viral Effect That is Not Prevented by Ganciclovir or Foscarnet Treatment. Transplantation (1996) 62(8):11028. doi: 10.1097/00007890-199610270-00014

183. Rolle A, Halenius A, Ewen EM, Cerwenka A, Hengel H, Momburg F. Cd2CD58 Interactions are Pivotal for the Activation and Function of Adaptive Natural Killer Cells in Human Cytomegalovirus Infection. Eur J Immunol (2016) 46(10):2420-5. doi: 10.1002/eji.201646492

184. Wang ECY, Pjechova M, Nightingale K, Vlahava VM, Patel M, Ruckova E, et al. Suppression of Costimulation by Human Cytomegalovirus Promotes Evasion of Cellular Immune Defenses. Proc Natl Acad Sci USA (2018) 115 (19):4998-5003. doi: 10.1073/pnas.1720950115

185. Hoffmann JC, Goke MN, Evers J, Rauker HJ, Bayer B, Manns MP. Reduced Serum Levels of a Soluble Form of the Human Adhesion Receptor Cd58 (LFA-3) in Patients With Inflammatory Bowel Disease. Z Gastroenterol (1996) 34(9):522-7.

186. Hargreaves R, Logiou V, Lechler R. The Primary Alloresponse of Human Cd4+ T Cells is Dependent on B7 (Cd80), Augmented by CD58, But Relatively Uninfluenced by CD54 Expression. Int Immunol (1995) 7 (9):1505-13. doi: 10.1093/intimm/7.9.1505

187. Sido B, Otto G, Zimmermann R, Muller P, Meuer S, Dengler TJ. Prolonged Allograft Survival by the Inhibition of Costimulatory Cd2 Signals But Not by
Modulation of CD48 (Cd2 Ligand) in the Rat. Transpl Int (1996) 9 Suppl 1: S323-7. doi: 10.1007/978-3-662-00818-8 80

188. Qin L, Chavin KD, Lin J, Yagita H, Bromberg JS. Anti-CD2 Receptor and Anti-CD2 Ligand (Cd48) Antibodies Synergize to Prolong Allograft Survival. J Exp Med (1994) 179(1):341-6. doi: 10.1084/jem.179.1.341

189. Sultan P, Schechner JS, McNiff JM, Hochman PS, Hughes CC, Lorber MI, et al. Blockade of CD2-LFA-3 Interactions Protects Human Skin Allografts in Immunodeficient Mouse/Human Chimeras. Nat Biotechnol (1997) 15 (8):759-62. doi: 10.1038/nbt0897-759

190. Archimbaud E, Thomas X, Campos L, Magaud JP, Dore JF, Fiere D. Expression of Surface Adhesion Molecules Cd54 (Icam-1) and CD58 (LFA-3) in Adult Acute Leukemia: Relationship With Initial Characteristics and Prognosis. Leukemia (1992) 6(4):265-71.

191. Archimbaud E, Campos L, Vila L, Thomas X. Potential Role for non-HLARestricted Cytotoxic Cells in the Immune Surveillance of Acute Leukemia. Immunol Lett (1993) 39(1):13-5. doi: 10.1016/0165-2478(93)90158-x

192. Li XM, Zhang LP, Wang YZ, Lu AD, Chang Y, Zhu HH, et al. Cd38+ CD58is an Independent Adverse Prognostic Factor in Paediatric Philadelphia Chromosome Negative B Cell Acute Lymphoblastic Leukaemia Patients. Leuk Res (2016) 43:33-8. doi: 10.1016/j.leukres.2015.12.015

193. Lee RV, Braylan RC, Rimsza LM. Cd58 Expression Decreases as Nonmalignant B Cells Mature in Bone Marrow and is Frequently Overexpressed in Adult and Pediatric Precursor B-cell Acute Lymphoblastic Leukemia. Am J Clin Pathol (2005) 123(1):119-24. doi: 10.1309/x5vv6fkjq6mublpx

194. Veltroni M, De Zen L, Sanzari MC, Maglia O, Dworzak MN, Ratei R, et al. Expression of CD58 in Normal, Regenerating and Leukemic Bone Marrow B Cells: Implications for the Detection of Minimal Residual Disease in Acute Lymphocytic Leukemia. Haematologica (2003) 88(11):1245-52.

195. Chen JS, Coustan-Smith E, Suzuki T, Neale GA, Mihara K, Pui CH, et al. Identification of Novel Markers for Monitoring Minimal Residual Disease in Acute Lymphoblastic Leukemia. Blood (2001) 97(7):2115-20. doi: 10.1182/ blood.v97.7.2115

196. Nagant C, Casula D, Janssens A, Nguyen VTP, Cantinieaux B. Easy Discrimination of Hematogones From Lymphoblasts in B-Cell Progenitor Acute Lymphoblastic Leukemia Patients Using CD81/CD58 Expression Ratio. Int J Lab Hematol (2018) 40(6):734-9. doi: 10.1111/ijlh.12912

197. Upadhyaya G, Guba SC, Sih SA, Feinberg AP, Talpaz M, Kantarjian HM, et al. Interferon-Alpha Restores the Deficient Expression of the Cytoadhesion Molecule Lymphocyte Function Antigen-3 by Chronic Myelogenous Leukemia Progenitor Cells. J Clin Invest (1991) 88(6):2131-6. doi: 10.1172/JCI115543

198. Komatsu F, Kajiwara M. A Lymphokine-Activated Killer (Lak)-Resistant Cell Line, and Low Expression of Adhesion Molecules LFA-3 and VCAM-1 on its Cell Surface. Oncol Res (1998) 10(5):263-9.

199. Billaud M, Rousset F, Calender A, Cordier M, Aubry JP, Laisse V, et al. Low Expression of Lymphocyte Function-Associated Antigen (LFA)-1 and LFA-3 Adhesion Molecules Is a Common Trait in Burkitt's Lymphoma Associated With and Not Associated With Epstein-Barr Virus. Blood (1990) 75 (9):1827-33. doi: 10.1182/blood.V75.9.1827.bloodjournal7591827

200. Gregory CD, Murray RJ, Edwards CF, Rickinson AB. Downregulation of Cell Adhesion Molecules LFA-3 and ICAM-1 in Epstein-Barr Virus-Positive Burkitt's Lymphoma Underlies Tumor Cell Escape From Virus-Specific T Cell Surveillance. J Exp Med (1988) 167(6):1811-24. doi: 10.1084/jem.167.6.1811

201. Veldman J, Visser L, Huberts-Kregel M, Muller N, Hepkema B, van den Berg A, et al. Rosetting T Cells in Hodgkin Lymphoma Are Activated by Immunological Synapse Components Hla Class II and CD58. Blood (2020) 136(21):2437-41. doi: 10.1182/blood.2020005546

202. Schneider M, Schneider S, Zuhlke-Jenisch R, Klapper W, Sundstrom C, Hartmann S, et al. Alterations of the CD58 Gene in Classical Hodgkin Lymphoma. Genes Chromosomes Cancer (2015) 54(10):638-45. doi: 10.1002/ gcc. 22276

203. Abdul Razak FR, Diepstra A, Visser L, van den Berg A. CD58 Mutations Are Common in Hodgkin Lymphoma Cell Lines and Loss of CD58 Expression in Tumor Cells Occurs in Hodgkin Lymphoma Patients Who Relapse. Genes Immun (2016) 17(6):363-6. doi: 10.1038/gene.2016.30

204. Cao Y, Zhu T, Zhang P, Xiao M, Yi S, Yang Y, et al. Mutations or Copy Number Losses of CD58 and TP53 Genes in Diffuse Large B Cell Lymphoma are Independent Unfavorable Prognostic Factors. Oncotarget (2016) 7 (50):83294-307. doi: 10.18632/oncotarget.13065 
205. Challa-Malladi M, Lieu YK, Califano O, Holmes AB, Bhagat G, Murty VV, et al. Combined Genetic Inactivation of Beta2-Microglobulin and CD58 Reveals Frequent Escape From Immune Recognition in Diffuse Large B Cell Lymphoma. Cancer Cell (2011) 20(6):728-40. doi: 10.1016/ j.ccr.2011.11.006

206. Otsuka Y, Nishikori M, Arima H, Izumi K, Kitawaki T, Hishizawa M, et al. Ezh2 Inhibitors Restore Epigenetically Silenced CD58 Expression in B-Cell Lymphomas. Mol Immunol (2020) 119:35-45. doi: 10.1016/j.molimm. 2020.01.006

207. Yoshida N, Karube K, Utsunomiya A, Tsukasaki K, Imaizumi Y, Taira N, et al. Molecular Characterization of Chronic-Type Adult T-Cell Leukemia/ Lymphoma. Cancer Res (2014) 74(21):6129-38. doi: 10.1158/00085472.CAN-14-0643

208. Palomero T, Couronne L, Khiabanian H, Kim MY, Ambesi-Impiombato A, Perez-Garcia A, et al. Recurrent Mutations in Epigenetic Regulators, RHOA and FYN Kinase in Peripheral T Cell Lymphomas. Nat Genet (2014) 46 (2):166-70. doi: 10.1038/ng.2873

209. Foreman NK, Rill DR, Coustan-Smith E, Douglass EC, Brenner MK. Mechanisms of Selective Killing of Neuroblastoma Cells by Natural Killer Cells and Lymphokine Activated Killer Cells. Potential for Residual Disease Eradication. Br J Cancer (1993) 67(5):933-8. doi: 10.1038/bjc.1993.173

210. Lorenz MG, Kantor JA, Schlom J, Hodge JW. Induction of Anti-Tumor Immunity Elicited by Tumor Cells Expressing a Murine LFA-3 Analog Via a Recombinant Vaccinia Virus. Hum Gene Ther (1999) 10(4):623-31. doi: $10.1089 / 10430349950018698$

211. Xu S, Wen Z, Jiang Q, Zhu L, Feng S, Zhao Y, et al. CD58, a Novel Surface Marker, Promotes Self-Renewal of Tumor-Initiating Cells in Colorectal Cancer. Oncogene (2015) 34(12):1520-31. doi: 10.1038/onc.2014.95
212. Mayer B, Lorenz C, Babic R, Jauch KW, Schildberg FW, Funke I, et al. Expression of Leukocyte Cell Adhesion Molecules on Gastric Carcinomas: Possible Involvement of LFA-3 Expression in the Development of Distant Metastases. Int J Cancer (1995) 64(6):415-23. doi: 10.1002/ijc.2910640611

213. Cai Q, Zhang M, Li Z. Potential Strategies Against Resistance to CAR T-Cell Therapy in Haematological Malignancies. Ther Adv Med Oncol (2020) 12:1758835920962963. doi: 10.1177/1758835920962963

214. Zhang Y, Liu Q, Liao Q. Long Noncoding Rna: A Dazzling Dancer in Tumor Immune Microenvironment. J Exp Clin Cancer Res (2020) 39(1):231 doi: 10.1186/s13046-020-01727-3

215. Nagaria TS, Wang H, Wang H. Predictive Molecular Markers in the Era of Immunotherapy. J Pancreatol (2020) 3(3):132-8. doi: 10.1097/jp9. 0000000000000043

216. Frangieh CJ, Melms JC, Thakore PI, Geiger-Schuller KR, Ho P, Luoma AM, et al. Multimodal Pooled Perturb-CITE-Seq Screens in Patient Models Define Mechanisms of Cancer Immune Evasion. Nat Genet (2021) 53 (3):332-41. doi: 10.1038/s41588-021-00779-1

Conflict of Interest: The authors declare that the research was conducted in the absence of any commercial or financial relationships that could be construed as a potential conflict of interest.

Copyright (c) 2021 Zhang, Liu, Yang and Liao. This is an open-access article distributed under the terms of the Creative Commons Attribution License (CC BY).

The use, distribution or reproduction in other forums is permitted, provided the original author(s) and the copyright owner(s) are credited and that the original publication in this journal is cited, in accordance with accepted academic practice. No use, distribution or reproduction is permitted which does not comply with these terms. 


\section{GLOSSARY}

\begin{tabular}{|c|c|}
\hline ADCC & antibody-dependent cellular cytotoxicity \\
\hline AICD & activation-induced cell death \\
\hline AITDs & autoimmune thyroid diseases \\
\hline ALL & acute lymphoid leukemia \\
\hline AML & acute myelogenous leukemia \\
\hline APC & antigen-presenting cell \\
\hline ATRA & all-trans retinoic acid \\
\hline $\mathrm{BL}$ & Burkitt's lymphoma \\
\hline $\mathrm{CHO}$ & Chinese hamster ovary \\
\hline CIA & collagen-induced arthritis \\
\hline CML & chronic myelocytic leukemia \\
\hline CMV & cytomegalovirus \\
\hline CNS & central nervous system \\
\hline CRC & colorectal cancer \\
\hline CTL & cytotoxic T lymphocyte \\
\hline DC & dendritic cell \\
\hline DLBCL & diffuse large B cell lymphoma \\
\hline E & erythrocyte \\
\hline EBV & Epstein-Barr virus \\
\hline EC & endothelial cell \\
\hline Fas-L & Fas ligation \\
\hline GC & gastric cancer \\
\hline GPI & glycosylphosphatidylinositol \\
\hline $\mathrm{HCC}$ & hepatocellular carcinoma \\
\hline $\mathrm{HL}$ & Hodgkin’s lymphoma \\
\hline HRS & Reed/Sternberg \\
\hline IBD & inflammatory bowel disease \\
\hline ICB & immune checkpoint blockade \\
\hline IEC & intestinal epithelial cell \\
\hline IEL & intraepithelial lymphocyte \\
\hline IS & immunological synapse \\
\hline LAK & lymphokine-activated killing \\
\hline LFA-3 & lymphocyte-function antigen 3 \\
\hline $\mathrm{mAb}$ & monoclonal antibody \\
\hline $\mathrm{MHC}$ & major histocompatibility complex \\
\hline MS & multiple sclerosis \\
\hline NF & nuclear factor \\
\hline NMO & neuromyelitis optica \\
\hline PHA & phytohemagglutinin \\
\hline PI-PLC & phosphatidylinositol-specific phospholipase C \\
\hline $\mathrm{PNH}$ & paroxysmal nocturnal hemoglobinuria \\
\hline RA & rheumatoid arthritis \\
\hline rv-CD58 & recombinant virus bearing CD58 \\
\hline sCD58 & soluble CD58 \\
\hline SMAC & supramolecular activation complex \\
\hline SNP & single-nucleotide polymorphism \\
\hline SRBC & sheep red blood cell \\
\hline T11TS & T11 target structure \\
\hline TCR & T cell receptor \\
\hline Tregs & T regulatory cells \\
\hline UV & ultraviolet. \\
\hline
\end{tabular}

